\title{
Genome-wide identification and expression analysis along the leaf developmental gradient of the sigma factor gene family in foxtail millet (Setaria italica)
}

\author{
Hongyun Liu ${ }^{1}$, Jinjin Cheng ${ }^{1}$, Siyuan Cheng ${ }^{2}$, Hui Fan ${ }^{1}$, Bo Wen ${ }^{3,4}$, Zheng Liu ${ }^{1,5 *}$ \\ ${ }^{1}$ College of Life Sciences, Hebei University, Baoding 071002, P.R., China. ${ }^{2}$ College of Biology, Hunan University, Changsha 410082, P.R., China. \\ ${ }^{3}$ School of Horticulture, Anhui Agricultural University, Hefei 230036, P.R., China. ${ }^{4}$ Key Laboratory of Genetic improvement and Ecophysiology of \\ Horticultural Crop, AnHui Province (Institute of Horticulture, Anhui Academy of Agricultural Sciences), Hefei 230039, P.R., China. ${ }^{5}$ Hebei Song-Ta-Po \\ Agricultural Development Corporation Limited, Quyang, Baoding, 073100, P.R., China.
}

\begin{tabular}{l}
\hline ARTICLE INFO \\
\hline Article history: \\
Received on: $24 / 05 / 2016$ \\
Revised on: $10 / 06 / 2016$ \\
Accepted on: $01 / 07 / 2016$ \\
Available online: $26 / 08 / 2016$ \\
\hline Key words: \\
Setaria italica, sigma factors, \\
gene family, phylogenetic \\
tree, protein domain, digital \\
gene expression
\end{tabular}

\begin{abstract}
Sigma factors are necessary for the initiation of transcription by RNA polymerase in bacteria and plastids of plants. In plants, a small family of nuclear genes is responsible for encoding the sigma factor proteins. In this study, a genome-wide identification and expression analysis of leaf gradient in millet (Setaria italica) were performed to characterize sigma factor genes and their proteins. By applying several bioinformatics tools, we identified chromosome locations of seven sigma factor genes in millet and their protein 3D structures. All these proteins contained three conserved domains of $\sigma-70$ family. These sigma factor genes have a closer phylogenetic relationship with their orthologs in maize than that in rice. The digital gene expression (DGE) analysis along the millet leaf developmental gradient indicated that Sisig1, Sisig5, Sisig6 showed extremely high expression levels in leaf middle and tip regions. Combining the conservation analysis of residues of each sigma factor protein with the DGE profiles of these proteins, it reveals that Sisig5 plays the housekeeping role compared with other Sisig proteins. Our study will facilitate the future research on crop evolution and the functional studies of sigma factor genes in millet.
\end{abstract}

\section{INTRODUCTION}

RNA polymerases play an important role in the first step of gene expression -transcription. As one of RNA polymerase subunits, sigma factors (Sigs) are necessary for RNA polymerase to recognize and bind the promoter and for controlling the rate of gene transcription $[1,2]$. Sigs have been grouped into $\sigma-70$ families and $\sigma-54$ families [3]. So far, all known plant plastid Sigs belong to the $\sigma-70$ group [4]. Although plant Sigs are encoded by a small family of nuclear genes, they determine whether the plastid RNA polymerase can bind to a specific promoter and thus set the first checkpoint to control the plastome gene expression [5]. Multiple Sigs have been found in the

\footnotetext{
* Corresponding Author

Email: liuzhengxp@yeah.net
}

plastids of higher plants [4]. In the model dicot plant Arabidopsis thaliana, six Sigs (SIG1-SIG6) have been identified and characterized [6]. In model monocot crop rice (Oryza sativa), six Sigs, OsSIG1 (Os-SigA), OsSIG2A, OsSIG2B, OsSIG3, OsSIG5 and OsSIG6, have also been found $[7,8,9]$ or predicted from the rice genome and the full-length cDNA sequencing project [10]. However, only two Sig genes (GRMZM2G143392 and GRMZM5G830932) have been identified in maize (Zea mays) [11, $12,13]$. In this study, six different gene loci representing seven distinct Sig genes of Setaria italic (Sisigs) were found through blast search of the genome of foxtail millet. Foxtail millet is self pollinating and its genome is relatively small, and therefore very suitable for whole genome research. In 2012, the complete genome sequencing of foxtail millet was successfully completed, making it as a model for the study of $\mathrm{C}_{4}$ photosynthesis and facilitating the study of crop morphology, physiological and biochemical and comparative functional genomics. 
Moreover, research has been done on millet by using the second generation of high-throughput sequencing technology [14]. The results provide genomic data for gene discovery and the genetic improvement of millet. The results also greatly enrich the genomic research containing comparative genetics and functional genomics [15]. All these studies provide reliable data resources for the study of Sisig genes. However, compared with the main crops of rice, wheat and maize, research on molecular genetics of millet started relatively late and most research findings are preliminary[16]. In order to obtain a better understanding of millet Sisigs that are critical for the expression of plastid genes, we performed a bioinformatic study and high-throughput digital gene expression (DGE) profiling on Sisig gene family in this important crop. The data from our studies will facilitate the future molecular and genetic studies in foxtail millet.

\section{MATERIALS AND METHODS}

\subsection{Identification of the sigma factor genes in Setaria italica}

The protein sequences of six Arabidopsis Sigs were downloaded from Phytozome (http://phytozome.jgi.doe.gov/pz/portal.html). The ID numbers of six rice Sig genes were obtained from oryzabase (http://www.shigen.nig.ac.jp/rice/oryzabase/) and their protein sequences were downloaded from NCBI database (http://www.ncbi.nlm.nih.gov/). To obtain all the Sisig genes, BLASTP searches were conducted in the Phytozome (http://www.phytozome.net/) and NCBI databases by using the rice and Arabidopsis Sig proteins as queries. Full-length genomic DNA, CDS (Coding DNA Sequence) and protein sequences of Sisigs of Setaria italica were downloaded from Phytozome. Besides, nine sig genes of maize were also obtained from Phytozome. According to the phylogenetic relationships between Sig protein sequences of A. thaliana, millet, rice as well as maize, the Sig genes of maize, rice and millet were renamed.

\subsection{Computational and bioinformatic analysis of the sigma factor genes and proteins}

The Size (aa), MW(Da) and PI of corresponding protein sequences were computed on the website of expasy (http://web.expasy.org/compute_pi/). The information of chromosomal location of Sisig genes were obtained from Phytozome and the chromosome location image of sigma factor genes was generated by MapInspect software [17]. To predict the exon-intron structure of the sigma factor genes, the genomic sequence of each gene was compared with its coding sequence (CDS) and was identified on GSDS (http://gsds.cbi.pku.edu.cn/) [18]. For a more intuitive understanding, these protein sequences of Sisig genes were submitted to the 3D LigandSite server (http://www.sbg.bio. ic.ac.uk/3dligandsite/) predict threedimensional models [19]. The Structural evaluation and stereochemical analyses were assessed by using RAMPAGE Ramachandran plot analysis (http://mordred.bioc.cam.ac.uk/ rapper/rampage.php)
Furthermore, the TargetP server (http://www.cbs.dtu.dk/services/ TargetP/) was used to predict the subcellular location of Sisig proteins [21]. The conserved motifs of Sisig protein sequences of foxtail millet were analyzed on MOTIF search server (http://www.genome.jp/tools/motif/) with the parameters: E-value of Pfam is 3e-10. Besides, the conserved sites of sigma factor protein sequences were analyzed on the Consurf server (http://consurf.tau.ac.il) with the default parameters. MEGA 4.0 was used to compute the evolutionary distances and construct the phylogenetic trees of Sigs in different plant species by using Clustal $\mathrm{W}$ for the alignment of amino acid sequences of Sigs. The neighbor-joining (NJ) method was applied to this analysis [22].

\subsection{Expression analysis of millet sigma factor genes along leaf development gradient by Digital Gene Expression Profile (DGE)}

Total RNA was extracted from leaf sheath (LS), leaf base area (LB), leaf middle area (LM) and leaf tip area (LT) by using TRIzol (Life Technologies, USA) in accordance with the manufacture's protocol. After RNase-free DNase treatment (Life Technologies, USA), the total RNA was checked for protein contamination and reagent contamination with a Nanodrop spectrophotometer and for RNA purity and degradation by agarose gel electrophoresis. mRNA was enriched by oligo(dT) magnetic beads (Theromo-fisher, USA). Three separate replicates for each leaf region were used.

Provided by a service from LC Sciences (Houston, USA), 12 DGE libraries in total were constructed in parallel using Illumina RNA ligation method (Illumina, San Diego, USA). A library with average length $350 \mathrm{bp}$, were fixed onto Illumina sequencing chip for cluster generation and performed deepsequencing using Illumina Genome Analyzer.

The raw data containing adaptor sequences, tags with low quality sequences and unknown nucleotides $\mathrm{N}$ were filtered to obtain clean reads with $36 \mathrm{nt}$ in length. Clean reads were then conducted for quality assessment, saturation evaluation and statistical analysis for experimental repeatability. These include classification of total and distinct reads, sufficiency analysis of transcripts coverage and correlation analysis of three parallel biological replicates. For annotation, all clean tags were mapped to the transcripts sequence of $S$. italica from the JGI Comparative Plant Genomics Portal (http://phytozome.jgi.doe.gov) by bowtie, only $1 \mathrm{bp}$ mismatch is allowed. The number of perfect clean reads corresponding to each gene was calculated and normalized to the number of reads per kilobase of exon model per million mapped reads (RPKM). The RPKMs of the seven millet sigma factor genes were then picked out and compared statistically.

\section{RESULTS AND DISCUSSION}

\subsection{Genome-wide characterization of the sigma factor genes in foxtail millet}

After the foxtail millet genome database was carefully searched, six gene loci were defined to contain seven Sisig genes 
(Table 1 and Fig. 1). It should be mentioned that there is one gene locus encoding two genes, i.e. locus Si026193m.g encodes the genes Sisig2A $a$ and Sisig2Ab. The amino acid sequence alignment by Clustal $\mathrm{W}$ revealed that the latter contains additional six successive amino acids (QLNLCF at position 440-445) compared with the former one. In general, the size of these seven proteins ranged from 484 to 566aa. When the structures of Sisig genes of foxtail millet were analyzed on the website of GSDS (Fig. 2), it was revealed that the number of exons ranged from six to nine: the Sisig1 and Sisig6 had 9 exons; the Sisig3 contained 7 exons; the other three Sisig genes had six exons each. The Sisig2Aa and
Sisig2Ab displayed the same gene structure. Based on gene duplication analysis, there was no segmental duplication event was identified. According to the subcellular location analyses of Sisig proteins, all the seven Sisig genes had chloroplast transit peptides (cTP) (Table 2). This indicated that all the products of these seven Sisig genes were targeted into chloroplast. This was consistent with the results by previous studies $[4,5]$. Sisig2Aa and Sisig2Ab contained the same cTP sequence, consisting of 36 amino acids. Among seven Sisig proteins, Sisig3 had the longest cTP sequence of 69 amino acids. Sisig1, Sisig2B, Sisig5 and Sisig6 each contained 65, 39, 44, 46 amino acids, respectively.

Table 1: Sigma factor genes identified in Setaria italica and their protein properties.

\begin{tabular}{lllccc}
\hline \multicolumn{1}{c}{ Gene name } & \multicolumn{1}{c}{ Gene loci } & Transcripts & Protein size(aa) & pI & MW(Da) \\
\hline Sisig1 & Seita.6G049900 & & 499 & 5.31 & 55700.48 \\
Sisig2Ab & Seita.8G112700 & Seita.6G049900.1 & 537 & 5.50 & 59572.87 \\
Sisig2Aa & Seita.8G112700 & Si026195m & 543 & 60291.74 \\
Sisig2B & Seita.9G461200 & Seita.9G461200.1 & 532 & 5.47 & 59299.6 \\
Sisig3 & Seita.3G124300 & Seita.3G124300.1 & 566 & 9.61 & 64546.09 \\
Sisig5 & Seita.3G126900 & & 484 & 5.90 & 55190.18 \\
Sisig6 & Seita.9G002700 & Seita.9G002700.1 & 554 & 6.95 \\
\hline
\end{tabular}

NOTE: Seita.8G112700 has two splice variants (Si026195m and SiO26193m). aa: amino acid; pI:Isoelectric point ; MW: protein molecular weight.

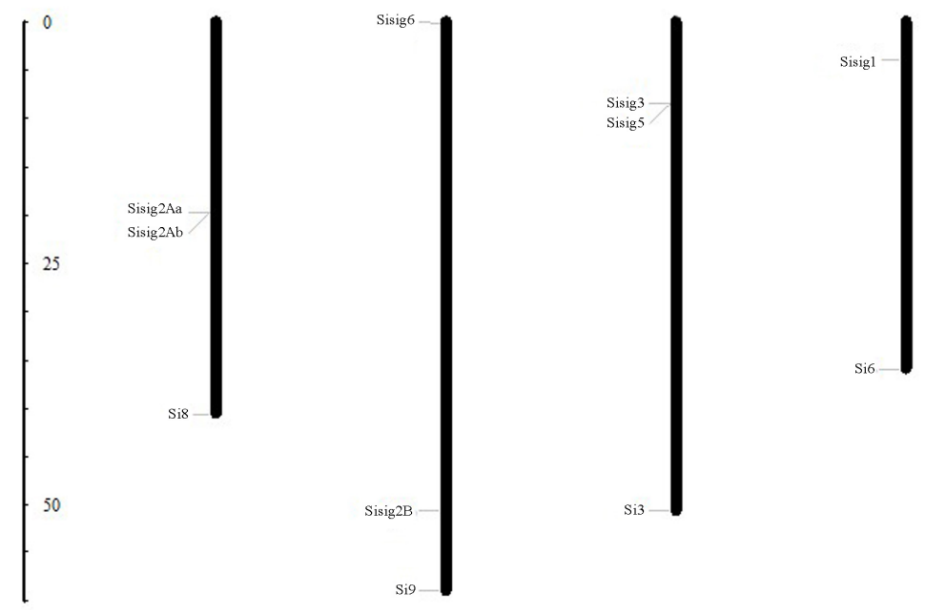

$\mathrm{M}$

Fig. 1: Chromosome locations of the sigma factor genes in millet.

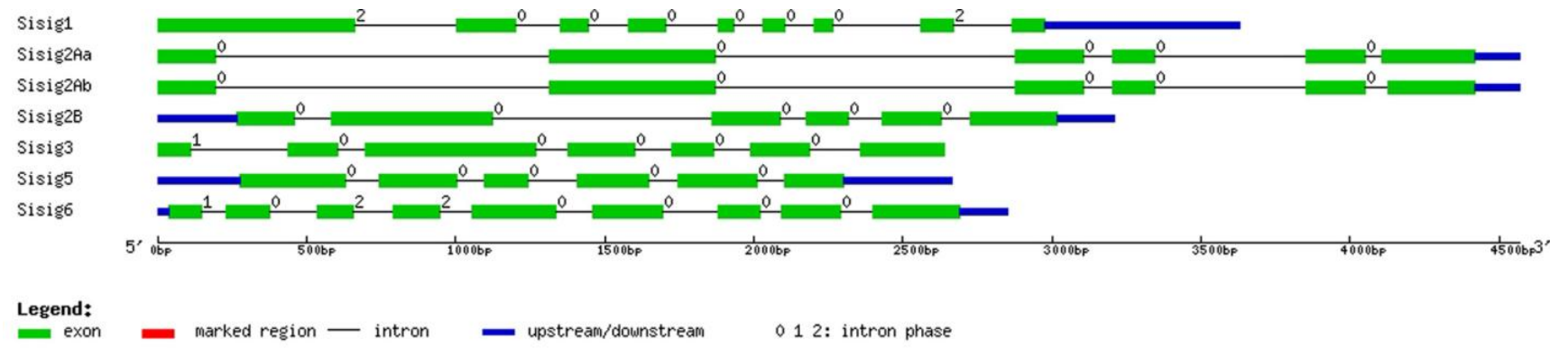

Fig. 2: Gene structures of the millet sigma factor gene family. Exons and introns are shown by filled boxes and single lines, respectively. Untranslated Regions (UTRs) are displayed by thick blue lines at both ends. Intron phases 0,1 , and 2 are indicated by numbers 0,1 , and 2 . 


\subsection{Three-dimensional (3D) structures of millet sigma factor proteins}

The three-dimensional models of the seven Sisig proteins were obtained from the 3D LigandSite server (Fig. 3). Through alignment with the protein sequences already existed in the database, the model images of these Sisig proteins were produced and coloured by rainbow from $\mathrm{N}$ to $\mathrm{C}$ terminus. These images provided a more intuitive understanding of the structure of Sisig proteins. In general, the 3D images of Sisig1, Sisig2Aa, Sisig2Ab, Sisig2B and Sisig5 showed the similar dimensional structures, looking like a "U" or "C". However, the 3D structures of Sisig3 and Sisig6 were irregular. In order to validate that the 3D models of Sisigs were displayed precisely, the ramachandran plot analyses using the RAMPAGE server were conducted.

The results showed that $87.9 \%, 87.6 \%, 89.8 \%, 89.4 \%$, $89.0 \%, 90.8 \%$, and $85.5 \%$ of amino acid residues were in the favored region; $7.8 \%, 8.8 \%, 7.3 \%, 7.6 \%, 9.4 \%, 5.6 \%$, and $10.4 \%$ in the allowed region in Sisig1, Sisig2Aa, Sisig2Ab, Sisig2B, Sisig3, Sisig5, and Sisig6, respectively (Fig.4).

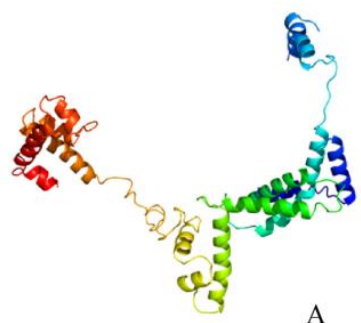

A

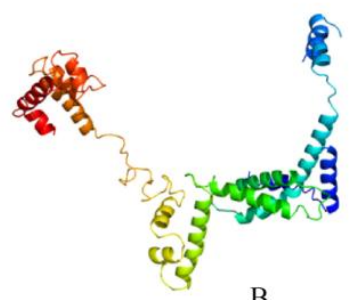

B

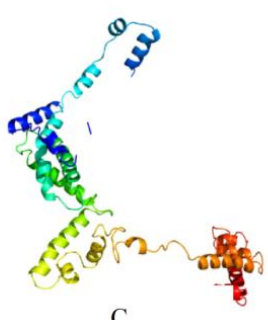

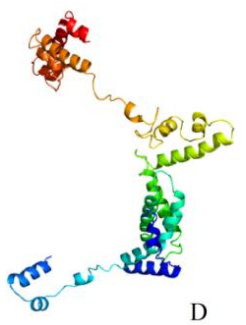

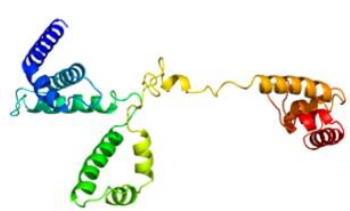

E
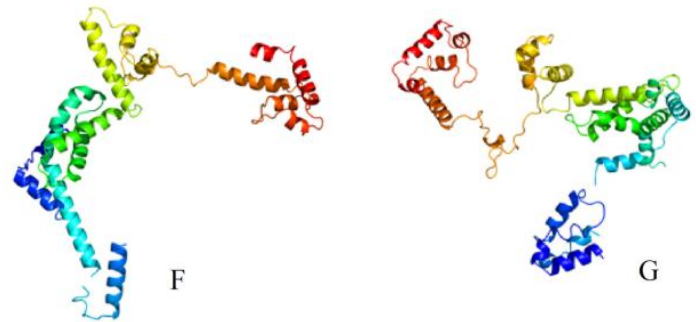

Fig. 3 The three-dimensional models of the millet sigma factor proteins (A: Sisig1; B: Sisig2Aa; C: Sisig2Ab; D: Sisig2B; E: Sisig3; F: Sisig5; G: Sisig6)
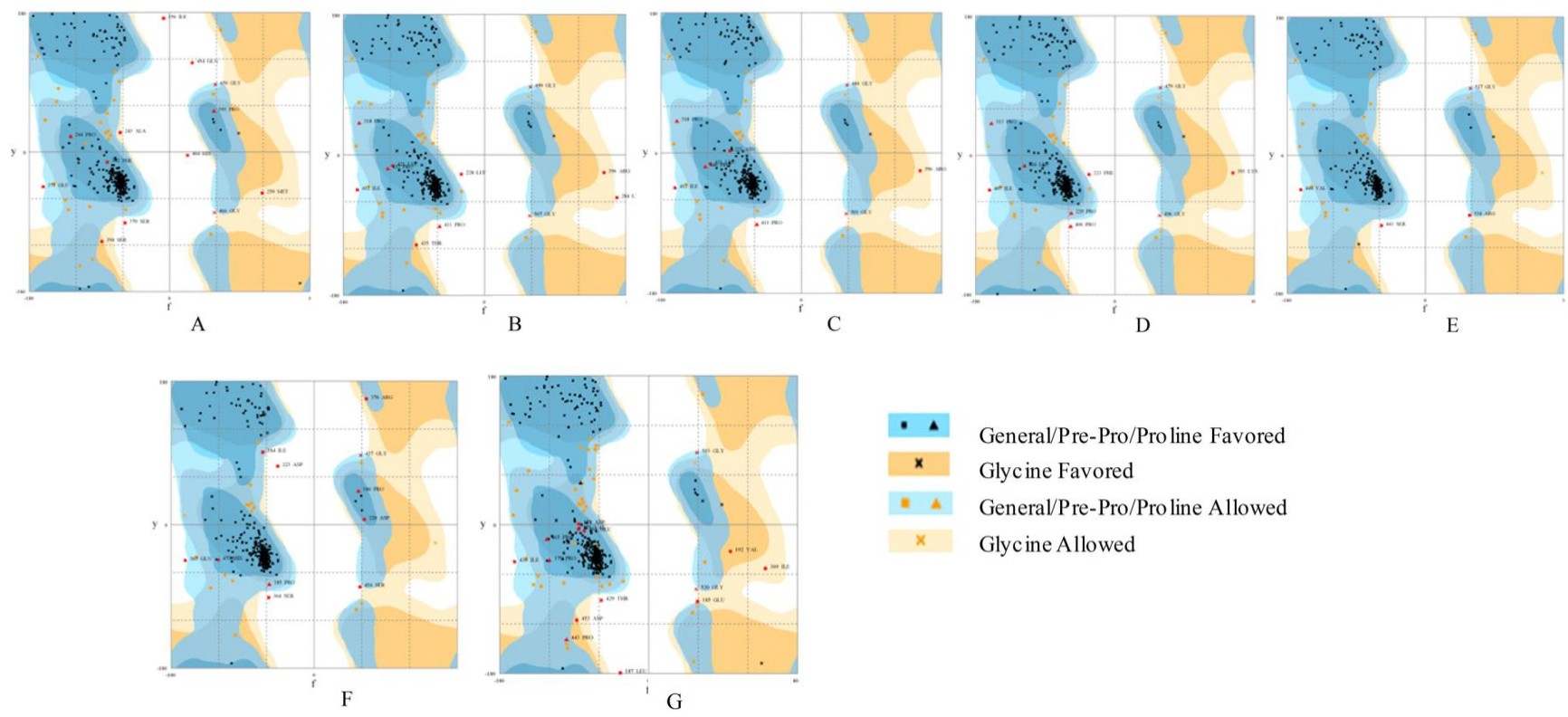

Genera/Pre-Pro/Pro line Favored Glycine Favored

Genera/Pre-Pro/Pro line Allowed

Glycine Allowed

Fig. 4 The Ramachandran plot analyses on 3D models of Sisig proteins (A: Sisig1; B: Sisig2Aa; C: Sisig2Ab; D: Sisig2B; E: Sisig3; F: Sisig5; G: Sisig6) 


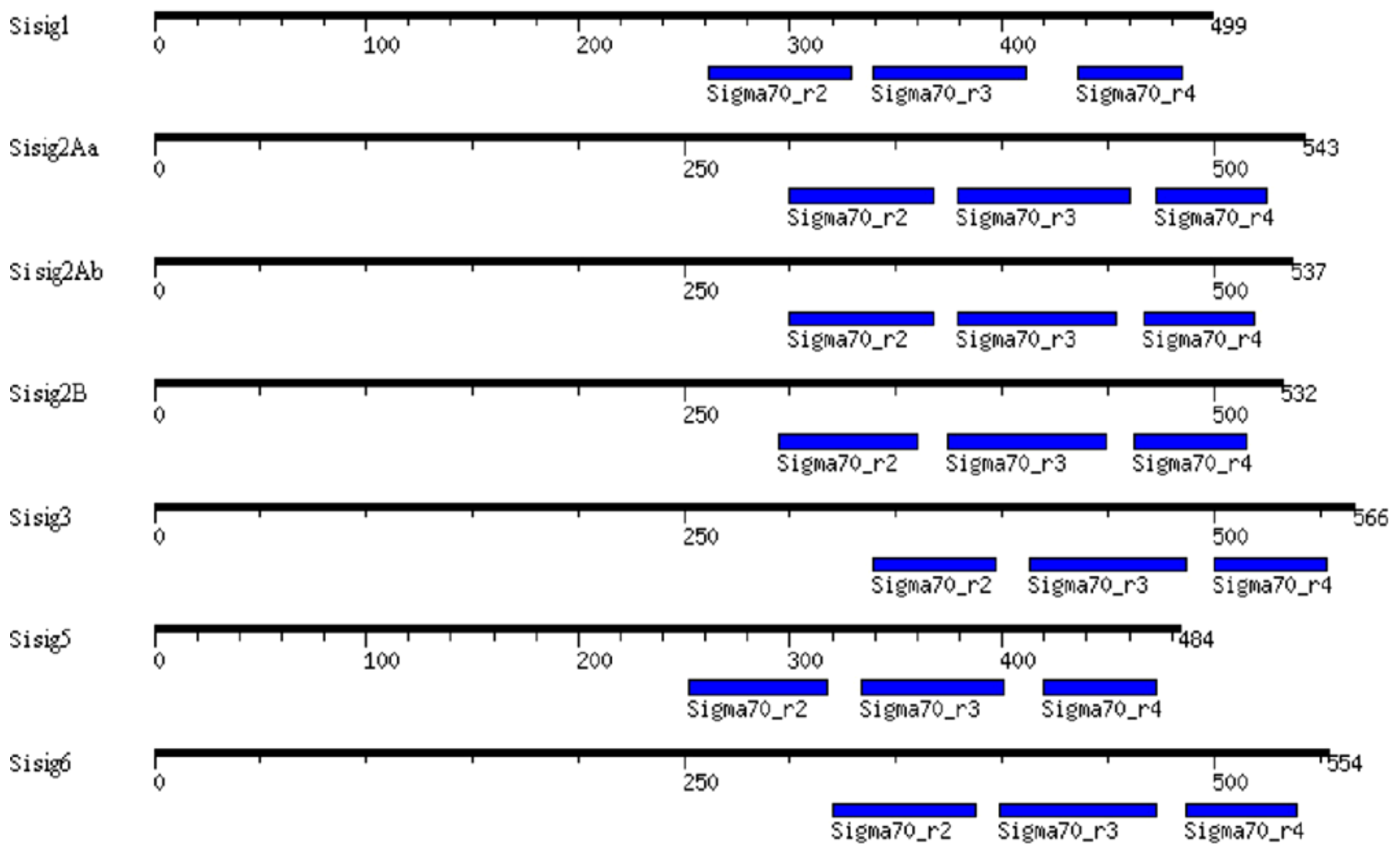

Fig. 5 The conserved motifs of sigma factor proteins in millet.

(Sigma70_r2, Sigma70_r3 and Sigma70_r4, respectively, represented in boxes with blue color).

\subsection{Analysis on the conserved motifs of the sigma factor proteins in millet}

The positions of the conserved motifs were generated by MOTIF (Fig. 5 and Suppl. 1). All the seven protein sequences contained three sigma-70 conserved domains, namely region 2, 3 and 4. Moreover, they were distributed on the $\mathrm{C}$-terminal region of the proteins, all locating behind the amino acid site of 250 . The conservation of these conserved regions correspond one-to-one with the same regions of bacterial sigma-70 factor and both species contain a large non-conservative N-terminal region [5], indicating similar evolutionary origins.

\subsection{Evolutionary conservation of amino acid positions in each Sisig protein}

The evolutionary conservation of amino acid positions in each Sisig protein which was based on the calculation of phylogenetic relations between homologous sequences was analyzed by the Consurf server (http://consurf.tau.ac.il/) with the default parameters (Table 3 and Suppl. 2-8). The result indicated that there existed differentially conserved degrees of residues in each protein. For instance, for the highest conserved scale of residues $(100 \%)$, Sisig5 accounted for the largest proportion $(36.98 \%)$ in the total residues of the protein, 
Table 3: The evolutionary conservation of the residues in each sigma factor protein in millet.

\begin{tabular}{|c|c|c|c|c|c|c|c|}
\hline \multirow[t]{2}{*}{ Conservation scale } & \multicolumn{7}{|c|}{ Percentage of residues in each protein (\%) } \\
\hline & Sisig1 & Sisig2Aa & Sisig2Ab & SiSisig2B & Sisig3 & Sisig5 & Sisig6 \\
\hline $100 \%$ & 26.45 & 13.44 & 11.73 & 11.47 & 27.03 & 36.98 & 8.84 \\
\hline $90 \%-100 \%$ & 15.43 & 10.50 & 9.87 & 11.47 & 6.54 & 0.00 & 13.72 \\
\hline $80 \%-90 \%$ & 8.62 & 7.55 & 7.64 & 6.77 & 22.61 & 11.16 & 9.93 \\
\hline $70 \%-80 \%$ & 11.82 & 6.81 & 6.89 & 8.27 & 12.90 & 7.64 & 10.65 \\
\hline $60 \%-70 \%$ & 12.22 & 12.52 & 12.29 & 8.27 & 7.95 & 19.21 & 13.00 \\
\hline $50 \%-60 \%$ & 9.42 & 14.92 & 14.53 & 16.54 & 10.60 & 10.95 & 14.44 \\
\hline $40 \%-50 \%$ & 5.61 & 18.05 & 18.06 & 18.98 & 6.54 & 6.41 & 11.55 \\
\hline $30 \%-40 \%$ & 7.02 & 9.95 & 11.55 & 11.65 & 3.18 & 5.58 & 9.57 \\
\hline $20 \%-30 \%$ & 2.81 & 5.89 & 6.14 & 6.02 & 2.47 & 2.07 & 7.58 \\
\hline $10 \%-20 \%$ & 0.60 & 0.37 & 1.30 & 0.56 & 0.18 & 0.00 & 0.72 \\
\hline Total & 100 & 100 & 100 & 100 & 100 & 100 & 100 \\
\hline
\end{tabular}

while Sisig6 accounted for the least proportion (8.84\%) among Sisig gene family. Similarly, when calculating the most variable residues (conservation scale $\leq 30 \%$ ) in each protein, it was also found that Sisig5 accounted for the least proportion $(2.07 \%)$ in the total residues of the protein and Sisig6 accounted for the largest proportion $(8.30 \%)$ among these proteins, indicating that the protein Sisig5 was evolutionary conserved compared with the protein Sisig6 when considering the conservation of the amino acid residues of the proteins. This also implied that the Sisig6 was a newly evolved protein. In all, analysis of the conserved sites of each protein would provide some information on the conservation degree of each protein and would further give us some hints on the evolutionary events of Sisig genes.

\subsection{Phylogenetic tree construction}

The Sig genes from millet, rice and maize were renamed according to their phylogenetic relationships with those of Arabidopsis (Suppl. 9). For example, the phylogenetically closest ortholog of Arabidopsis Atsigl in millet was renamed as Sisig1. It was found that there are 9 sigma factor genes in maize, which are 1.5 times in number than that in Arabidopsis, rice and millet. It is speculated that additional steps of gene duplication would occur in maize during evolution.

Phylogenetic tree construction of millet, rice, maize and Arabidopsis Sig proteins was generated by the software of Mega4.0 (Fig. 6). According to the phylogenetic relationship between Arabidopsis and millet, Sisig genes of millet were clarified into five types (Table 5): two Sisig2 genes, and Sisig1, Sisig3, Sisig5 and Sisig6 each in one. Additionally, the orthologs of Atsig4 were not found in rice, maize and millet, possibly Atsig4 was a newly evolved gene after the monocot-dicot divergence. As a whole, millet Sisig genes had close phylogenetic relationships with rice and maize. Moreover, Sisig genes had closer relationships with their orthologs in maize. It is probably due to that fact that millet and maize belong to $\mathrm{C}_{4}$ plants, while rice belongs to $\mathrm{C}_{3}$ plant. Thus the phylogenetic relationship of Sig genes could, to some extent, reflect the evolutionary relationships of these plants. Rice is the typical model gramineous plant for comparative genomic studies because of its slow evolutionary rate, making it better to keep the traits of ancestral genome sequences [23]. Maize and millet both belong to $\mathrm{C}_{4}$ monocotyledonous crops.
So far, the whole genome sequencing works on rice, maize and millet have been completed [24, 25, 26], and some Sig genes from Arabidopsis, rice and maize were well characterized. Recent studies on Arabidopsis provided some evidences on specific roles of each Atsig gene [5, 6, 27, 28]. In rice and maize, some results on the studies of Sig genes were also obtained [7, 9, 10, 29, 30]. According to the phylogenetic relationship of Sig proteins between the millet and the other three plants, specific roles of Sisig genes could be inferred to some extent. Atsig1 is thought to be involved in light response as high-light stress changes the binding between Atsig1 protein and its target promoters [6]. It was found that accumulation of rice Ossigl transcripts is significantly higher in green shoots than in dark-grown shoots or in roots [7]. Further, Ossig1 regulates some gene expressions which are critical for the establishment of photosystem $\mathrm{I}$ in rice mature chloroplasts, thus participating in the maintenance of photosynthesis [10]. Similarly, the expression pattern of Zmsigl is aligned with the light-triggered plastid development processes [29, 30]. The close phylogenetic relationship between millet Sisigl and sigl genes in Arabidopsis, rice and maize suggests that Sisig1 would also be involved in light-regulated development and photosynthesis. Indeed, promoter analysis of Sisig 1 revealed that there exist a considerable number of cis-acting elements related to light regulation (Suppl. 8). Atsig5 was identified to bind some target promoters in response to blue light and various abiotic stresses (high light, high salinity and osmotic pressure as well as low temperature) [31, 32, 33]. For example, Atsig5 specifically binds the $p s b D$ blue-light responsive promoter in Arabidopsis. Similarly, Sisig5 promoter contains elements related to stress signals, such as low temperature, salt and water stresses (Suppl. 8). In addition, Atsig4 plays a specific role in the transcription of $n d h F$ [34], a plastid gene encoding a subunit of the plastid NDH complex. However, no sig4 genes were found in rice, maize and millet. It would be interesting to reveal how $n d h F$ genes are regulated in these important monocotyledonous crops. Besides, some specific Sigs such as SIG1, SIG2, and SIG6 are necessary for the expression of cytomin induced chloroplast genes in Arabidopsis [35, 36]. However, in millet, only Sisig3, which is phylogenetically distant to these Arabidopsis Sigs, was found to have promoter elements related to cytokinin. Thus, it is worthwhile to pay attention to the special function of Sisig3 on cytomin regulated expression of plastid genes. 


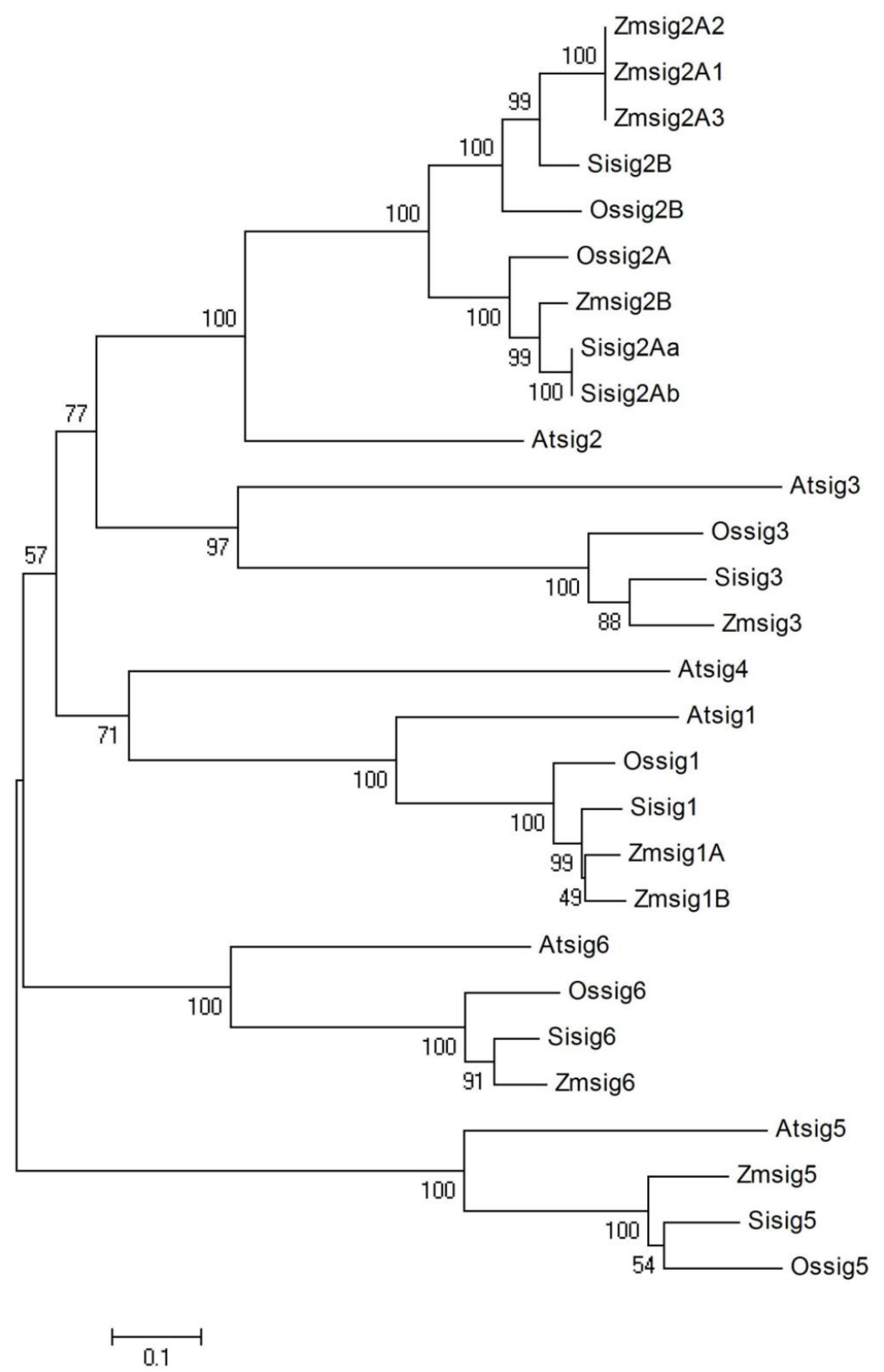

Fig. 6 Phylogenetic tree of foxtail millet, Arabidopsis, rice and maize Sig proteins. The joint unrooted tree was generated using MEGA4.0 by the neighbor joining method. Bootstrap values from 1000 replicates were indicated at each branch. Abbreviations: Os, Oryza sativa; At, Arabidopsis thaliana; Si, Setaria italica and Zm, Zea mays.

\subsection{Expression profiling of millet sigma factor genes along leaf development gradient}

The continuous developmental pattern from leaf base to tip has been well studied in developing grass leaves, such as maize and rice $[37,38]$. Comparative gene expression analysis of $\mathrm{C}_{4}$ and $\mathrm{C}_{3}$ crops along leaf gradient will be helpful for addressing how $\mathrm{C}_{4}$ traits are developed. Although sigma factors play essential roles in the initiation of expression of chloroplast genes and therefore in the efficiency of photosynthesis, all developmental gradient studies neglected the leaf sheath and none of these reports mentioned the behavior of the sigma factor gene family along such gradient except the one by Aubry et al [39]. In our study (Fig. 7), we found that six out of seven members of millet Sisig genes showed the lowest expression levels in leaf sheath area. 


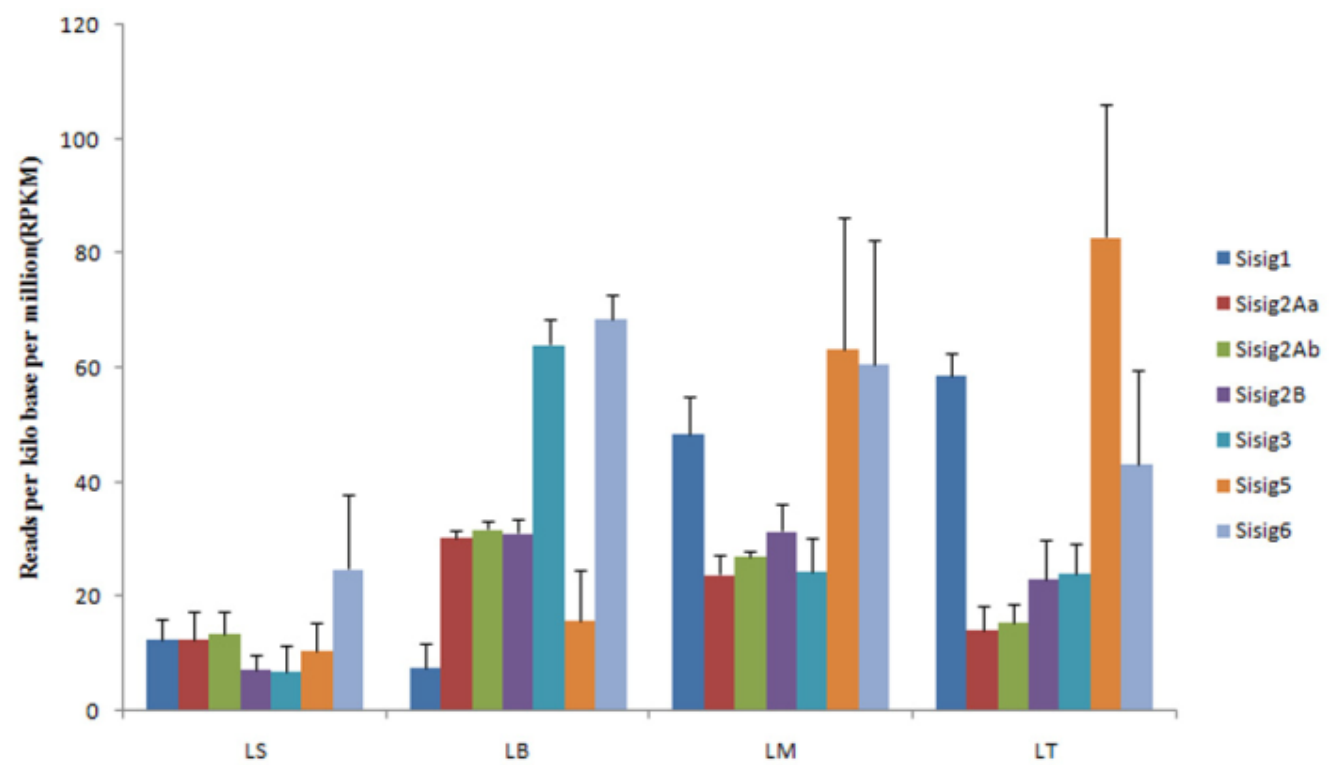

Fig. 7: Expression profiles of millet sigma factor genes along leaf developmental gradient (LS: leaf sheath; LB: leaf base; LM: leaf middle; LT: leaf tip)

Although it was found four sigma factor genes exhibit escalating pattern along leaf gradient in two independent $\mathrm{C}_{4}$ lineages (Cleome gynandra and maize) [39], only one gene (i.e. Sisig5) fits this pattern in millet leaf. The gene Sisig1 exhibited the similar expression pattern as that of Sisig5 in general, although its expression level in leaf sheath area was 1.5 times as high as that in leaf base area. Five Sisig genes (i.e. Sisig2Aa, Sisig2Ab, Sisig2B, Sisig3 and Sisig6) shared the same expression patterns along developmental gradient. They all showed significantly increased expression levels from leaf sheath area towards leaf basa area, i.e. the expression levels Sisig2Aa, Sisig2Ab, Sisig2B, Sisig6 in leaf base area were 3 times as high as in leaf sheath area, even that of Sisig 3 reached 9 fold change. Then the expression levels finally decrease gradually from leaf base area towards leaf tip area, suggesting that functional divergence of these genes compared with that of Sisig1 and Sisig5. Additionally, Fig.7 also showed that expressions of Sisig1, Sisig5 and Sisig6 were significantly upregulated in leaf middle and tip areas as their RPKM values reached over 50, suggesting that these genes are main genes involved in photosynthesis. The Sisig 5 was identified to show the highest expression levels (64 and 83 RPKM values, respectively) among the seven sigma factors in leaf middle and tip areas, revealing that it plays a critical role in regulating genes responsible for photosynthesis and leaf development. Combining the residue conservation analysis which identified that Sisig5 protein was the most conserved protein in amino acid sequence among Sisig protein family, it could be concluded that Sisig5 plays the housekeeping function to maintain chloroplast development in millet. To our knowledge, this is the first study to identify the gene expression patterns of millet Sisig gene family along leaf development gradient. This work could provide a foundation for the functional identification of millet sigma factor gene family and for the study of the relationships among leaf morpho gradient, developmental gradient and gene expression patterns of this gene family in the future.

\section{CONCLUSION}

Although the functional domains of the seven Sisig proteins all contain conserved region 2, 3, 4, their 3D figures displayed the slightly different spatial structures among them which may result in their functional differences. The phylogenetic study of the sigma factor genes displayed us the phylogenetic distances of the Sisig genes of millet with their orthologues other plant species, and from this, specific functions of a Sisig gene could be inferred from the previous studies on the phylogenetically closed gene in other plant species.

Millet is a model plant for the research on $\mathrm{C}_{4}$ photosynthesis and it maintains strong tolerance to drought and barren conditions. Through the study of expression profiling of millet sigma factor genes along leaf development gradient, it was found that the gene Sisigl exhibited the similar expression pattern as that of Sisig 5 in general. The highest expression levels of Sisig 5 in leaf middle and tip regions among all Sisig genes and the most conservation of amino acids of Sisig5 protein among these sigma factor proteins inferred that Sisig5 plays the housekeeping function to maintain chloroplast development in millet.

With the whole genome of millet been sequenced already, it facilitates us with in-depth study of millet Sisig gene family, which would be very helpful for our comprehensive understanding on the expressions and regulation of the chloroplastrelated genes in this important crop. As the genomic analyses of Sisig gene family were fulfilled by this study, the next step should concentrate on characterization of these genes through molecular and biochemical assays. 


\section{ACKNOWLEDGEMENTS}

We thank the Natural Science Foundation of Hebei Province (No. C2015201176), the Scientific Research Foundation for the Returned Overseas Chinese Scholars by State Education Ministry of China (No. 2011-1139), the Project for Improvement of Integrated Strength of Universities in Central and Western Areas of China (Plant Diversity and Resources Utilization), the Cutting-edge and Characteristic Disciplines of Biology (Botany), the Research Innovation Program for Postgraduates of Hebei Province (S2016022), the Opening Grant in Key Laboratory of Genetic improvement and Ecophysiology of Horticultural Crop, Anhui Province (Institute of Horticulture, Anhui Academy of Agricultural Sciences) (No.AHZDSYS201401)for funding.

\section{REFERENCES}

1. Borukhov S, Severinov K. Role of the RNA polymerase sigma subunit in transcription initiation. Res Microbiol. 2002; 153(9):557-562.

2. Lysenko EA. Analysis of the evolution of the family of the Sig genes encoding plant sigmafactors. Russ J Plant Physiol. 2006; 53(5):605614.

3. Ishizaki Y, Tsunoyama Y, Hatano K, Ando K., Kato K, Shinmyo A, Kobori M, Takeba G, Nakahira Y, Shiina T. A nuclear-encoded sigma factor, Arabidopsis SIG6, recognizes sigma-70 type chloroplast promoters and regulates early chloroplast development in cotyledons. Plant J. 2005; 42(2):133-144

4. Lerbs-Mache S. Function of plastid sigma factors in higher plants: regulation of gene expression or just preservation of constitutive transcription? Plant Mol Biol. 2011; 76(3-5):235-249.

5. Lysenko EA. Plant sigma factors and their role in plastid transcription. Plant Cell Rep. 2007; 26(26):845-859.

6. Hanaoka M, Kato M, Anma M, Tanaka K. SIG1, a sigma factor for the chloroplast RNA polymerase, differently associates with multiple DNA regions in the chloroplast chromosomes in vivo. Int J Mol Sci. 2012; 13(10):12182-12194.

7. Tozawa Y, Tanaka K, Takahashi H, Wakasa K. Nuclear encoding of a plastid $\sigma$ factor in rice and its tissue- and light-dependent expression. Nucleic Acids Res. 1998; 26(2):415-419.

8. Kasai K, Kawagishi-Kobayashi M, Teraishi M, Ito Y, Ochi K, Wakasa $\mathrm{K}$, Tozawa Y. Differential expression of three plastidial sigma factors, OsSIG1, OsSIG2A, and OsSIG2B, during leaf development in rice. Biosci Biotech Bioch. 2004; 68(4):973-977.

9. Kubota Y, Miyao A, Hirochika H, Tozawa Y, Yasuda H, Tsunoyama Y, Niwa Y, Imamura S, Shirai M, Asayama M. Two novel nuclear genes, OsSIG5 and OsSIG6, encoding potential plastid sigma factors of RNA polymerase in rice: tissue-specific and light-responsive gene expression. Plant Cell Physiol. 2007; 48(48):186-192.

10. Tozawa Y, Teraishi M, Sasaki T, Sonoike K, Nishiyama Y, Itaya M, Miyao A, Hirochika H. The plastid sigma factor SIG1 maintains photosystem I activity via regulated expression of the psaA operon in rice chloroplasts. Plant J. 2007; 52(1):124-132.

11. Tan S, Troxler RF. Characterization of two chloroplast RNA polymerase sigma factors from Zea mays: Photoregulation and differential expression. Proc Natl Acad Sci USA. 1999; 96(96):53165321.

12. Beardslee TA, Roy-Chowdhury S, Jaiswal P, Buhot L, Lerbs-Mache $\mathrm{S}$, Stern DB, Allison LA. A nucleus-encoded maize protein with sigma factor activity accumulates in mitochondria and chloroplasts. Plant J. 2002; 31(2):199-209.

13. John CR, Smith-Unna RD, Woodfield H, Covshoff S, Hibberd JM. Evolutionary convergence of cell-specific gene expression in independent lineages of $\mathrm{C}_{4}$ grasses. Plant Physiol. 2014; 165(1):62-75.

14. Jia GQ, Huang XH, Zhi H, Zhao Y, Zhao Q, Li WJ, Chai Y, Yang LF, Liu KY, Lu HYet al. A haplotype map of genomic variations and genome-wide association studies of agronomic traits in foxtail millet (Setaria italica). Nat Genet. 2013; 45(8):957-961.

15. Yuan M, Qu LJ, Wang XJ, Qian Q, Yang WC, Wang T, Kong HZ, Jiang GM, Chong K. Research advances on plant science in China in 2013. Chinese Bulletin of Botany. 2014; 49:347-406.

16. Feng XL, Zhao ZH, Wang XM, Qiu FC, Song GL, Wang DQ, Su X, Zhang XL, Wang F. Recent Research Progress in Foxtail Millet (Setaria italica). Agr Sci \& Technol. 2014; 15:564-570, 575.

17. Lin YX, Jiang HY, Chu ZX, Tang XL, Zhu SW, Cheng BJ. Genomewide identification, classification and analysis of heat shock transcription factor family in maize. BMC Genomics. 2011; 12(1):76.

18. Guo AY, Zhu QH, Chen X, Luo JC. GSDS: a gene structure display server. Hereditas (Beijing). 2007; 29(8):1023-1026.

19. Wass MN, Kelley LA, Sternberg MJ. 3DLigandSite: predicting ligandbinding sites using similar structures. Nucleic Acids Res. 2010; 38 (Suppl.):W469-473.

20. Lovell SC, Davis IW, Arendall WB, de Bakker PIW, Word JM, Prisant MG, Richardson JS, Richardson DC. Structure validation by $C \alpha$ geometry: $\phi, \psi$ and $C \beta$ deviation. Proteins. 2003; 50:437-450.

21. Emanuelsson O, Nielsen H, von Heijne G. Predicting subcellular localization of proteins based on their N-terminal amino acid sequence. J Mol Biol. 2000; 300(4):1005-1016.

22. Tamura K, Dudley J, Nei M, Kumar S. MEGA4: molecular evolutionary genetics analysis (MEGA) software version 4.0. Mol Biol Evol. 2007; 24(8):1596-1599.

23. Zhang Q, Wang ZY, Ma XL, Nie LM, Wang HL, Wang JP. Comparative analysis of paleopolyploidy evolution in genomes of Setaria italica and Zea mays. J Henan Agric Sci. 2014; 43(6):10-15.

24. Schnable PS, Ware D, Fulton RS, Stein JC, Wei F, Pasternak S, Liang C, Zhang J, Fulton L, Graves TA, et al. The B37 maize genome: Complexity, diversity and dynamics. Science. 2009; 326(5956):11121115.

25. Bennetzen JL, Schmutz J, Wang H, Percifield R, Hawkins J, Pontaroli AC, Estep M, Feng L, Vaughn JN, Grimwood J, et al. Reference genome sequence of the model plant Setaria. Nat Biotechnol. 2012; 30(6):555-561.

26. Zhang GY, Liu X, Wang J. Genome sequence of foxtail millet (Setaria italica) provides insights into grass evolution and biofuel potential. Nat Biotechnol. 2012; 30(6):549-556.

27. Isono K, Shimizu M, Yoshimoto K, Niwa Y, Satoh K, Yokota A, Kobayashi H. Leaf-specifically expressed genes for polypeptides destined for chloroplasts with domains of $\sigma^{70}$ factors of bacterial RNA polymerases in Arabidopsis thaliana. Proc Natl Acad Sci USA. 1997; 94(26): 14948-14953.

28. Schweer J, Türkeri H, Kolpack A, Link G. Role and regulation of plastid sigma factors and their functional interactors during chloroplast transcription-Recent lessons from Arabidopsis thaliana. Eur J Cell Biol. 2010; 89(12):940-946.

29. Lahiri SD, Yao J, McCumbers C, Allison LA. Tissue-specific and light-dependent expression within a family of nuclear-encoded $\sigma$-like factors from Zea mays. Mol Cell Biol Res Commun. 1999; 1(1):14-20.

30. Lahiri SD, Allison LA. Complementary expression of two plastidlocalized sigma-like factors in maize. Plant Physiol. 2000; 123(3): 883-894.

31. Yao J, Roy-Chowdhury S, Allison LA. AtSig5 is an essential nucleusencoded Arabidopsis $\sigma$-like factor. Plant Physiol. 2003; 132(2):739-47.

32. Tsunoyama Y, Ishizaki Y, Morikawa K, Kobori M, Nakahira Y, Takeba G, Toyoshima Y, Shiina T. Blue light-induced transcription of plastid-encoded $p s b D$ gene is mediated by a nuclear-encoded transcription initiation factor, AtSig5. Proc Natl Acad Sci USA. 2004; 101(9):3304-3309.

33. Nagashima A, Hanaoka M, Shikanai T, Fujiwara M, Kanamaru K, Takahashi H, Tanaka K. The multiple-stress responsive plastid sigma factor, SIG5, directs activation of the $p s b D$ blue light-responsive promoter (BLRP) in Arabidopsis thaliana. Plant Cell Physiol. 2004; 45(4):357-368.

34. Favory JJ, Kobayahi M, Tanaka K, Peltier G, Kreis M, Valay JG, Lerbs-Mache S. Specific function of a plastid sigma factor for ndhF gene transcription. Nucleic Acids Res. 2005; 33(18):5991-5999. 
35. Borsellino L. Influence of light and cytokinin on organellar phage-type RNA polymerase transcript levels and transcription of organellar genes in Arabidopsis thaliana. $\mathrm{PhD}$ thesis, Humboldt Universität $\mathrm{zu}$ Berlin. 2011.

36. Cortleven A, Schmülling T. Regulation of chloroplast development and function by cytokinin. J Exp Bot. 2015; 66(16):4999-5013.

37. Pick TR, Bräutigam A, Schlüter U, Denton AK, Colmsee C, Scholz U, Fahnenstich H, Pieruschka R, Rascher U, Sonnewald U, Weber AP. Systems analysis of a maize leaf developmental gradient redefines the current C4 model and provides candidates for regulation. Plant Cell. 2011; 23(12):4208-4220.

38. Wang L, Czedik-Eysenberg A, Mertz RA, Si Y, Tohge T, Nunes-Nesi A, Arrivault S, Dedow LK, Bryant DW, Zhou W, et al. Comparative analyses of $\mathrm{C} 4$ and $\mathrm{C} 3$ photosynthesis in developing leaves of maize and rice. Nat Biotechnol. 2014; 32(11):1158-1165.
39. Aubry S, Kelly S, Kumpers BMC, Smith-Unna RD, Hibberd JM. Deep evolutionary comparison of gene expression identifies parallel recruitment of trans-factors in two independent origins of $\mathrm{C}_{4}$ photosynthesis. PLOS Genet. 2014; 10(6):e1004365.

\section{How to cite this article:}

Hongyun Liu, Jinjin Cheng, Siyuan Cheng, Hui Fan, Bo Wen, Zheng Liu., Genome-wide identification and expression analysis along the leaf developmentalgradient of the sigma factor gene family in foxtail millet (Setaria italica). J App Biol Biotech. 2016; 4 (04): 011-030. DOI: 10.7324/JABB.2016.40402

\section{SUPPLEMENTARY DATA}

Suppl. 1 The position information of the conserved motifs in sigma factor proteins of millet.

\begin{tabular}{|c|c|c|c|}
\hline Query & Pfam & $\begin{array}{l}\text { Position } \\
\text { (independent E-value) }\end{array}$ & Description \\
\hline \multirow{3}{*}{ Sisig 1} & Sigma70_r3 & $339 . .411(1.2 \mathrm{e}-12)$ & PF04539, Sigma-70 region 3 \\
\hline & Sigma70_r2 & $262 . .329(2.9 \mathrm{e}-15)$ & PF04542, Sigma-70 region 2 \\
\hline & Sigma70_r4 & $436 . .485(2.1 \mathrm{e}-10)$ & PF04545, Sigma-70 region 4 \\
\hline \multirow{3}{*}{ Sisig $2 A a$} & Sigma70_r4 & $473 . .525(2.3 e-20)$ & PF04545, Sigma-70 region 4 \\
\hline & Sigma70_r2 & $300 . .368(4.3 e-16)$ & PF04542, Sigma-70 region 2 \\
\hline & Sigma70_r3 & $379 . .460(3.3 e-14)$ & PF04539, Sigma-70 region 3 \\
\hline \multirow{3}{*}{ Sisig $2 \mathrm{Ab}$} & Sigma70_r4 & $467 . .519(2.2 \mathrm{e}-20)$ & PF04545, Sigma-70 region 4 \\
\hline & Sigma70_r3 & 379..454(4.6e-18) & PF04539, Sigma-70 region 3 \\
\hline & Sigma70_r2 & $300 . .368(4.3 e-16)$ & PF04542, Sigma-70 region 2 \\
\hline \multirow{3}{*}{ Sisig 2B } & Sigma70_r4 & $462 . .515(1.5 \mathrm{e} 19)$ & PF04545, Sigma-70 region 4 \\
\hline & Sigma70_r3 & $374 . .449(2.6 \mathrm{e}-17)$ & PF04539, Sigma-70 region 3 \\
\hline & Sigma70_r2 & $295 . .360(2.2 \mathrm{e}-16)$ & PF04542, Sigma-70 region 2 \\
\hline \multirow{3}{*}{ Sisig 3} & Sigma70_r4 & $500.553(3.3 e-12)$ & PF04545, Sigma-70 region 4 \\
\hline & Sigma70_r3 & 413..487(1.8e-12) & PF04539, Sigma-70 region 3 \\
\hline & Sigma70_r2 & $339 . .397(6.3 e-11)$ & PF04542, Sigma-70 region 2 \\
\hline \multirow{3}{*}{ Sisig 5} & Sigma70_r3 & $334 . .401(6.2 \mathrm{e}-14)$ & PF04539, Sigma-70 region 3 \\
\hline & Sigma70_r4 & $240.473(5.9 \mathrm{e}-12)$ & PF04545, Sigma-70 region 4 \\
\hline & Sigma70_r2 & $252 . .318\left(8.9 \mathrm{e}^{-11}\right)$ & PF04542, Sigma-70 region 2 \\
\hline \multirow{3}{*}{ Sisig 6} & Sigma70_r3 & $399.473(3 e-13)$ & PF04539, Sigma-70 region 3 \\
\hline & Sigma70_r2 & $320 . .388(2.6 e-19)$ & PF04542, Sigma-70 region 2 \\
\hline & Sigma70_r4 & $487 . .539(3.3 e-16)$ & PF04545, Sigma-70 region 4 \\
\hline
\end{tabular}




\section{ConSurf Results}

\begin{tabular}{|c|c|c|c|c|}
\hline & 11 & 21 & 31 & 41 \\
\hline MTAT PAVIGL & $S A G N R L A$ A $S$ & GPA $A D L A$ & DA H P L Q F A P & K I A V V V A \\
\hline $\begin{array}{c}e \underset{f}{f} \in \\
f\end{array}$ & $\begin{array}{c}\mathrm{b} b \in \underset{\mathrm{f}}{\mathrm{e}} \mathrm{b} \mathrm{s} \\
\mathbf{s}\end{array}$ & $\underset{f}{b e b b b e b b e e}$ & $e \overline{b e e e b e b e e}$ & $\bar{e} e \mathrm{e} e \mathrm{~b} b \bar{b} b e$ \\
\hline 51 & 61 & 71 & 81 & 91 \\
\hline H RASAS SYP & A G H $A R$ H A V R & A RNHSA A L & A P P P P P P P P E & D P A A L A P D D \\
\hline eeeeeeee & eeeeeebbe & $\begin{array}{l}e b e e e b e e e b \\
f\end{array}$ & eeeeeeee & eeeec \\
\hline 101 & 111 & 121 & 131 & 141 \\
\hline SAFEFES S E & A I V L L QR SML & L P F E D & E DEE E H $S$ E S & L F A K S T V VA \\
\hline e e eeeebbe & $\begin{array}{r}b \mathrm{bb} b \mathrm{~b} e \mathrm{e} e \mathrm{e} \\
\mathbf{s} \quad \mathrm{f} f \mathrm{f}\end{array}$ & $\begin{array}{l}e \in e b e e e b e e \\
f f f \quad f f\end{array}$ & e e e & eee \\
\hline 151 & 161 & 171 & 181 & 191 \\
\hline SG SAR RR & M GRR G T R & K VAISPEIM & Q S R NRIY I R G & TVSKELLTH \\
\hline $\begin{array}{ll}b & e b \\
f & f\end{array} \quad f f$ & eeeeeeee & $\begin{array}{r}\mathrm{b} e \text { e e } \mathrm{b} b \text { e } e \mathrm{~b} b \\
\mathbf{f} \mathbf{s}\end{array}$ & $\begin{array}{l}e b e e \\
f \quad f\end{array}$ & $\begin{array}{r}b \mathrm{~b} b e \in b \mathrm{~b} \in \mathrm{e} b \\
\mathbf{s}\end{array}$ \\
\hline 201 & 211 & 221 & 231 & 241 \\
\hline QVVQLSK K I K & DGI W $Q$ H $Q R S$ & $\mathrm{~K} L \mathrm{~L}$ N E P & $Q \mathrm{~L} A Q S \mathrm{~L}$ & I S A \\
\hline $\begin{array}{c}e b b e b b e e b e \\
\mathbf{s} \quad \mathbf{s} \quad \mathbf{s}\end{array}$ & $\underset{\mathbf{s}}{e b b e b e e b e e}$ & $\begin{array}{lll}e b & f f & f\end{array}$ & $\begin{array}{l}e \text { e e } b b \in b b e \\
\mathbf{f} \quad \mathbf{s} \mathbf{s} \mathbf{s}\end{array}$ & $\mathrm{b} b \mathrm{e}$ \\
\hline 251 & 261 & 271 & 281 & 291 \\
\hline$R E S F L A R E M L$ & TMSNIRLVIS & I A Q K Y D N & $E I A D L I Q G G L$ & I G L L R G I E KF \\
\hline $\begin{array}{c}b \in b b b b \text { e e e } b \\
\mathbf{s} f f\end{array}$ & $\begin{array}{l}e \mathrm{eb} b \in \mathrm{b} b \mathrm{~b} b \\
\mathbf{f} \mathbf{s} \boldsymbol{f} \mathbf{s} \quad \mathbf{s}\end{array}$ & $\begin{array}{l}\mathrm{b} b e e \mathrm{~b} e \mathrm{~b} e \mathrm{~b} \\
\mathbf{s} \boldsymbol{s} \quad \mathrm{f} \quad \mathrm{f}\end{array}$ & $\begin{array}{l}e b b e b b e e b b \\
s \quad f s \quad f f s s\end{array}$ & $\begin{array}{l}b b b b \in b b e e b \\
s \boldsymbol{s} \boldsymbol{s} \boldsymbol{f} \boldsymbol{s} \boldsymbol{s} \boldsymbol{f}\end{array}$ \\
\hline DASRGFRIST & 311 & SRALA N S KT & $\begin{array}{l}331 \\
\text { FR L P T Y L HER }\end{array}$ & I I A I R S A K Y A \\
\hline $\begin{array}{l}e, e e b e b b b \\
f \quad f f f \quad s s s\end{array}$ & $\begin{array}{l}b b b b b b e e b b \\
s \boldsymbol{s} s \boldsymbol{s} \boldsymbol{f} f \mathbf{s} s\end{array}$ & $\begin{array}{l}b e b b b e e e e \\
s \quad f f f f\end{array}$ & $\begin{array}{c}b \in b e e b e e b \\
\text { fsf f ff }\end{array}$ & $\begin{array}{l}b \in b b e \in b \in b e \\
\mathbf{s} \quad \mathbf{s} f \quad s f\end{array}$ \\
\hline LE D Q GI A P T T & $\begin{array}{l}361 \\
\text { ENIA LNIS }\end{array}$ & $\begin{array}{l}371 \\
\text { E K K V NATEA }\end{array}$ & $\begin{array}{l}381 \\
\text { VNK V L S L DQ Q }\end{array}$ & $\begin{array}{l}391 \\
\text { A F P S L N GL P G }\end{array}$ \\
\hline $\begin{array}{l}b e e e b b e e b b \\
\mathbf{s} \quad f \quad f f\end{array}$ & $\begin{array}{c}e, b b e b b e e e \\
\mathbf{s} \quad \quad s f f f\end{array}$ & $\begin{array}{r}e e b \text { e } b e e b \\
f s \text { f } f \quad s\end{array}$ & $\begin{array}{r}b e e b b e b e e e \\
f \quad f f\end{array}$ & iff $f f$ \\
\hline $\begin{array}{l}401 \\
\text { E T L H S Y I E DE }\end{array}$ & $\begin{array}{l}411 \\
\mathbf{N} \mathbf{V} \mathbf{A} \mathbf{N} \mathrm{D} \mathbf{P} \text { W H G F }\end{array}$ & $\frac{421}{\text { EER Y L KE E VN }}$ & $\begin{array}{l}431 \\
\text { NLINST LNER }\end{array}$ & ER D I I R L Y H G \\
\hline 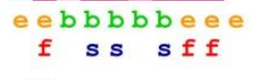 & $\begin{array}{c}e=b e e b b \\
f \quad f f\end{array}$ & $\begin{array}{l}e \in b b b e e b b e \\
f \quad s f \quad f s\end{array}$ & $\begin{array}{ccc}e b b & b b e b e e \\
\mathbf{s} & \mathbf{s} & f\end{array}$ & $\begin{array}{l}e \in b b e b b b \\
f \quad s \quad s \quad s\end{array}$ \\
\hline $\begin{array}{l}451 \\
\text { I G K Q H T W E D }\end{array}$ & $\begin{array}{l}461 \\
\text { I S R Q F G L S R E }\end{array}$ & $\begin{array}{l}471 \\
\text { R V R Q VG L VAM }\end{array}$ & $\begin{array}{l}481 \\
\text { E K L K H A A R R K }\end{array}$ & $\begin{array}{l}491 \\
\text { H L D }\end{array}$ \\
\hline $\begin{array}{l}b=e j b \in b \\
s \quad f \quad s f s\end{array}$ & $\begin{array}{l}\mathrm{b} b \text { b } \in \mathrm{b} \in \mathrm{b} \\
\mathbf{s} \mathbf{s} \quad \mathrm{f} \mathbf{s}\end{array}$ & $\begin{array}{l}e b e e b b b b b b \\
f s f f \quad s s \quad s\end{array}$ & $\begin{array}{l}e \text { e } b e e e e e \\
f \mathbf{f f f} \text { ff }\end{array}$ & $\underset{f}{e b} e^{e b}$ \\
\hline
\end{tabular}

The conservation scale:

$\begin{array}{lllllllll}1 & 2 & 3 & 4 & 5 & 6 & 7 & 8 & 9\end{array}$

Variable Average Conserved

e - An exposed residue according to the neural-network algorithm.

b - A buried residue according to the neural-network algorithm.

f - A predicted functional residue (highly conserved and exposed).

s - A predicted structural residue (highly conserved and buried).

- Insufficient data - the calculation for this site was performed on less than $10 \%$ of the sequences. 
Suppl. 2 Evolutionary conservation of amino acid positions in Sisig 1 protein.

\section{ConSurf Results}

\begin{tabular}{|c|c|c|c|c|}
\hline MACLA PQFKW & 1 P S A TA H A T S & $\frac{21}{\text { S S SRCSA RV }}$ & $\begin{array}{l}31 \\
\text { HCA V T S A A A V }\end{array}$ & $\begin{array}{l}41 \\
\text { V D T D R A N }\end{array}$ \\
\hline $\begin{array}{l}e b \text { fff } \\
f \text { ffe }\end{array}$ & eeeebbee & eeeeeebeb & $\begin{array}{l}e b b b e e b b b b \\
\mathbf{s} \quad f\end{array}$ & $b e b e$ ebeee \\
\hline 51 & 61 & 71 & & 91 \\
\hline A A Q L R I A F S A & PALQRNFEST & A SEA L L NEE & $A V V E A A A E A$ & $V A L A R A A B A$ \\
\hline beeeeeee & eeeeebeee & $\underset{f}{b b b e b b} \underset{f}{f}$ & $\begin{array}{l}\mathrm{b} b \mathrm{~b} b \mathrm{~b} b \mathrm{~b} \in \mathrm{b} \\
\mathbf{s} \mathbf{s} \mathbf{s} \mathbf{s}\end{array}$ & $\begin{array}{c}\mathrm{bb} b \mathrm{~b} \in \mathrm{b} b \mathrm{~b} \in \mathrm{b} \\
\mathbf{s} \mathbf{s} \quad \mathbf{s} \quad \mathbf{f}\end{array}$ \\
\hline 01 & 111 & 121 & 131 & 141 \\
\hline$L E V V Q M V Q N$ & N N $\mathrm{Q} Q \mathrm{PVIR} Q \mathrm{~K}$ & KVVD Y L A NE & I L R TEIQ P $S$ & P D G Y A N D V L L \\
\hline $\begin{array}{l}b \text { e } b b e b b e e \\
s \quad f\end{array}$ & eeeeeeee & eeeeebebee & beeeeeeeb & eeeeeeebe \\
\hline 151 & 161 & 171 & 181 & 191 \\
\hline E DFESYG IMA & GGGE L D D A $Q$ & Y T ENIA VKSA & RQSERRARRT & RAAIKA A T T V \\
\hline eeeeeeee & $\bar{e}$ ebee eeee & $\underset{f}{e e e}$ & $\begin{array}{l}e \text { e e e e e e e } \\
\mathbf{f} \quad \mathbf{f}\end{array}$ & eeeeeeeee \\
\hline 201 & 11 & 221 & 231 & 241 \\
\hline S K T A T S S & K K K R P K G S S P & SMNPLGS L WK & MTGRRLITAK & E EVEFSEIQ \\
\hline eeeeeeeee & eeeeeeee & $\underset{f f}{f} \mathbf{f} f$ & $\begin{array}{c}e b b e a b e b e \\
f \quad s \quad s f\end{array}$ & $\begin{array}{ll}e \in b & b b e b e \\
f f & \quad s \quad s f\end{array}$ \\
\hline 251 & 261 & 271 & 281 & 291 \\
\hline D L L K L E A I Q A & E L T & T F $\mathrm{Q}$ W A T A A R & T DE K T L R K R L & D H G I Y C K N R M \\
\hline $\begin{array}{c}e b b e b e b e e \\
s \quad f\end{array}$ & $\begin{array}{r}\text { e e e e e e } \\
f\end{array}$ & $\begin{array}{c}\text { e e b bebbe } \\
\text { f s } \mathbf{s}\end{array}$ & $\underset{f}{f} f$ & $\begin{array}{c}e \in b e e b e e e b \\
\mathbf{s} \quad f f \quad s\end{array}$ \\
\hline 301 & 311 & 321 & 331 & 341 \\
\hline T T N V R L V I S & I AREFE GPGM & D L Y D L I Q E GM & Q G L I RG A E K F & DASKGFRST \\
\hline $\begin{array}{l}b \in b b b e b b b b \\
\mathbf{s} \quad \mathbf{s} \mathbf{s} \mathbf{s} s \mathbf{s}\end{array}$ & $\begin{array}{l}b b e e b e e b \\
\text { s } s f f \text { ff } f\end{array}$ & $\begin{array}{c}e b e e b b e e b b \\
f f \boldsymbol{s} \boldsymbol{s} f \boldsymbol{f} \mathbf{s}\end{array}$ & $\begin{array}{l}e b b b e b b e e e \\
f \mathbf{s} \quad f \boldsymbol{s} \boldsymbol{f} f \boldsymbol{f}\end{array}$ & $\begin{array}{l}\text { ff ff f } f \mathbf{s} \\
\text { f }\end{array}$ \\
\hline 351 & 361 & 371 & 381 & 391 \\
\hline Y S H W W I K Q A M & R K S V S Q S Q I & F R L P A H M V EA & SYR VKECTKR & L R R K L R R P T \\
\hline $\begin{array}{l}b \mathrm{~b} b \mathrm{~b} b \mathrm{~b} \\
\mathbf{s} \mathbf{s} \mathbf{s} \mathbf{s} \mathbf{s}\end{array}$ & $\begin{array}{l}e e b b e e e e b \\
f f \quad s f f f f f\end{array}$ & $\begin{array}{l}b \in b b b b b b e b \\
s f s s \quad s \quad s f\end{array}$ & $\begin{array}{l}\mathrm{b} b \in \mathrm{b} \in \mathrm{e} b \mathrm{~b} e \mathrm{e} \\
\mathbf{s} \boldsymbol{s} \mathbf{s} \quad \mathbf{f}\end{array}$ & $\begin{array}{r}\mathrm{b} e \mathrm{e} e \mathrm{e} e \mathrm{e} e \\
\mathbf{f} \mathbf{f}\end{array}$ \\
\hline $\begin{array}{l}401 \\
\text { N E EIAVD T GM }\end{array}$ & $\begin{array}{l}411 \\
\text { P I K R V E }\end{array}$ & $\frac{421}{L P K \text { Y S V S L D S }}$ & $\frac{431}{\mathrm{~K} I \mathrm{G} S \mathrm{~T}} \mathbf{\mathrm { D }} \mathbf{M} \mathbf{T} \mathbf{Y}$ & 441 Q EVT A \\
\hline $\begin{array}{c}e \in b b \\
f \quad s \quad f \quad f\end{array}$ & 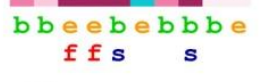 & $\underset{f}{f} \mathbf{f} f$ & $f \quad f \quad f \quad f$ & $\begin{array}{c}b \in b b b e e b b e \\
f f\end{array}$ \\
\hline $\begin{array}{l}451 \\
\text { DP S A E T A E E M }\end{array}$ & $\frac{461}{\text { L N R L S M K K D V }}$ & $\begin{array}{l}471 \\
\text { HQA LD T L T A R }\end{array}$ & $\begin{array}{l}481 \\
\text { EK Q V V V L R F G }\end{array}$ & $\begin{array}{l}491 \\
\text { L E D GR I R T LQ }\end{array}$ \\
\hline $\mathbf{f} \quad \mathbf{f} \mathbf{f}$ & $b b e e b^{b}$ & $\begin{array}{r}e \mathrm{~b} b e e b e e \\
\mathbf{s} \mathbf{s} \quad \mathbf{s} \quad \mathbf{f}\end{array}$ & $\begin{array}{l}e \in b b e b e b b \\
f \quad f \quad f \quad s\end{array}$ & $\begin{array}{r}\text { fff f } f \boldsymbol{s} f\end{array}$ \\
\hline 501 & 511 & 521 & 531 & 541 \\
\hline EI GN I MGVSR & E R I R Q I ESGA & FRKLRS K K R V & K A L K D Y L V P V & G N W \\
\hline - & $\begin{array}{l}b \in b \in b \\
s f \quad s\end{array}$ & eeeee & $\begin{array}{c}e \in b e e b b b e e \\
\quad s \quad s \quad f\end{array}$ & $\begin{array}{rl}e e & e \\
f\end{array}$ \\
\hline
\end{tabular}

The conservation scale:

$\begin{array}{lllllllllll}1 & 2 & 3 & 4 & 5 & 6 & 7 & 8 & 9\end{array}$

Variable Average Conserved

e - An exposed residue according to the neural-network algorithm.

b - A buried residue according to the neural-network algorithm.

f - A predicted functional residue (highly conserved and exposed).

s - A predicted structural residue (highly conserved and buried).

- Insufficient data - the calculation for this site was performed on less than $10 \%$ of the sequences. 


\section{ConSurf Results}

\begin{tabular}{|c|c|c|c|c|}
\hline$\frac{1}{M A C I A P}$ & $\begin{array}{l}11 \\
\text { A P S A TAHATS }\end{array}$ & $\begin{array}{l}21 \\
\text { s s s }\end{array}$ & 31 & $\begin{array}{l}41 \\
\text { VDT T R N }\end{array}$ \\
\hline $\begin{array}{l}e f b \text { ff } \\
f f\end{array}$ & eeeeebbee & e e e e bebeb & $\begin{array}{l}e b \mathrm{~b} b e \mathrm{~b} b \mathrm{~b} b \\
\mathbf{s} \quad \mathrm{f}\end{array}$ & $b e b e e b e e e e$ \\
\hline 51 & 61 & 71 & 81 & 91 \\
\hline$A A Q L \quad F$ & PALQRNFEST & L A S E A L L NEE & $\mathrm{A} V \mathrm{~V} \mathrm{~A} A \mathrm{~A} A \mathrm{E} \mathrm{A}$ & $V A L A R A A E A$ \\
\hline$b \in b e e b e b e e$ & eeeeebeee & $\underset{f}{b b b e b b b e e e}$ & $\begin{array}{lll}\mathrm{b} b \mathrm{~b} b \mathrm{~b} b \mathrm{~b} & \in \mathrm{b} \\
\mathbf{s} & \mathbf{s} \mathbf{s} \mathbf{s}\end{array}$ & $\begin{array}{c}\mathrm{b} b \mathrm{~b} b \\
\mathbf{s} \mathbf{s} \quad \mathbf{s}\end{array}$ \\
\hline 101 & 111 & 121 & 131 & 141 \\
\hline dL EVVQMVQN & N N H Q PVIR Q K & KVVD Y LANE & I L R TEI Q P S S & P D G Y A N D V L L \\
\hline $\begin{array}{l}\mathrm{b} e e \mathrm{~b} b e \mathrm{~b} b e e \\
\mathbf{s} \quad \mathbf{s}\end{array}$ & eec & e e e e bebee & $\begin{array}{c}b \\
f\end{array}$ & eeeeeeebe \\
\hline 151 & 161 & 171 & 181 & 191 \\
\hline E D FES Y G I MA & GGGE L D D A Q & Y TENIAVKSA & RQSERRARRT & RAAIKAATTV \\
\hline eeeeeeee & eebeeeeee & 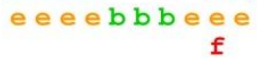 & $\underset{f}{e e e e c e e ~ e ~}$ & eeeeeeeb \\
\hline 201 & 211 & 221 & 231 & 241 \\
\hline RASQKTATS S & K K K R P K G S S P & S MN P L GS L WK & MTGRRLLTAK & EEVEFSGIQ \\
\hline $\bar{e} \bar{e} \bar{e} e \bar{e} e$ e & eeeeeeeee & $\begin{array}{l}e f f \in b b e \\
f f \quad f\end{array}$ & $\begin{array}{c}e b b e j b e b e \\
f \quad s \quad f f\end{array}$ & $\begin{array}{l}e \in b e b \bar{b} e e b e \\
f f \quad s \quad s f\end{array}$ \\
\hline 251 & 261 & 271 & 281 & 291 \\
\hline$D I L K L E A I Q A$ & ELTEYNGGQP & TFSQWATAAR & T DEKTLRK L & D H G I Y C K N R M \\
\hline $\begin{array}{c}e b \vec{b} e b e \in b e e \\
\quad s \quad f\end{array}$ & $\begin{array}{r}\text { ebeeeeeeee } \\
f\end{array}$ & eee ebbebee & $\underset{f}{b e e e c b e e b}$ & $\begin{array}{r}e \in b e \in b e e b \\
s \quad f f \quad s\end{array}$ \\
\hline 301 & 311 & 321 & 331 & 341 \\
\hline VTS NVRLVIS & I A R E F E $G$ P G M & D L Y D L I Q E GM & Q G LIRGAEK F & DASKGFRST \\
\hline $\begin{array}{l}b \in b b b \in b b b b \\
\mathbf{s} \quad \mathbf{s} \quad \mathbf{f} s \mathbf{s}\end{array}$ & $\begin{array}{l}b b e e b e e e b \\
\text { s } f f f \text { ff } f\end{array}$ & $\begin{array}{c}e b e b b e e b b \\
f f \boldsymbol{s} \boldsymbol{f} \boldsymbol{f} \boldsymbol{s}\end{array}$ & $\begin{array}{l}e b b b e b b e e b \\
f \mathbf{s} \quad \boldsymbol{f} \boldsymbol{s} \boldsymbol{s} \boldsymbol{f} \boldsymbol{f} \boldsymbol{s}\end{array}$ & 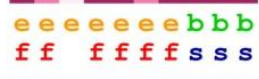 \\
\hline 351 & 361 & 371 & 381 & 391 \\
\hline Y S H W W I K Q A M & R K S V SEQS Q I & F R L PA H M E A & SYRVKECTKR & LRRKLRRRPT \\
\hline $\begin{array}{l}b b b b b b e e b b \\
s \boldsymbol{s} \boldsymbol{s} \boldsymbol{s} \boldsymbol{f} \boldsymbol{f} \mathbf{s}\end{array}$ & $\begin{array}{l}e \in b b \text { e e e b e b } \\
f f \quad f f f \boldsymbol{f}\end{array}$ & $\begin{array}{l}b \in b b b b b b \in b \\
\mathbf{s} f \mathbf{s} \quad \mathbf{s} \quad f \mathbf{s}\end{array}$ & $\begin{array}{l}b \text { e } b \text { e e beee } \\
\mathbf{s} f \mathbf{f} \quad \mathbf{f}\end{array}$ & $\begin{array}{r}b e c e e e e e \\
f \quad f\end{array}$ \\
\hline $\begin{array}{l}401 \\
\text { N E EI AVD T GM }\end{array}$ & $\begin{array}{l}411 \\
\text { P I K R V E A A V N }\end{array}$ & $\frac{421}{\text { L P K Y S V S L D S }}$ & $\begin{array}{l}431 \\
\text { K I G S T D M T Y Q }\end{array}$ & $\frac{441}{\text { EV T ADP S A E T }}$ \\
\hline $\begin{array}{r}e \mathrm{~b} b \\
f \quad \boldsymbol{s}\end{array}$ & $\begin{array}{c}\mathrm{b} b \underset{f}{\mathrm{f}} \boldsymbol{e} \mathrm{s} \in \mathrm{b} b \mathrm{~b} \\
\mathbf{f}\end{array}$ & $\begin{array}{l}\mathrm{b} \in \mathrm{f} \\
\mathbf{f} \mathbf{f}\end{array}$ & $\mathbf{f} \mathbf{f} f \mathbf{f} f$ & $\begin{array}{l}\mathrm{f} b \mathrm{~b} e \mathrm{e} e \mathrm{e} \\
\mathbf{f}\end{array}$ \\
\hline $\begin{array}{l}451 \\
\text { A E E M L N R L S M }\end{array}$ & $\begin{array}{l}461 \\
\text { K KDVHQA L D T }\end{array}$ & $\begin{array}{l}471 \\
\text { L T A R E K Q V V V }\end{array}$ & $\frac{481}{L R \text { F G L E D GR I }}$ & $\begin{array}{l}491 \\
R \text { T L Q E I GN I M }\end{array}$ \\
\hline$\underset{f}{b} e \overline{b b b} e e b \bar{b}$ & $\begin{array}{c}e=b \mathrm{~b} e \mathrm{~b} b e e \\
\mathbf{f} \quad \mathbf{s} \mathbf{s}\end{array}$ & $\begin{array}{l}\vec{b} e \text { e e e b be } \\
\mathbf{s} \text { ff } \mathbf{f} \mathbf{s}\end{array}$ & $\begin{array}{l}b \in b b b e=e b \\
f \quad s \quad f f\end{array}$ & $\begin{array}{l}e b b \in e b b \in b b \\
\boldsymbol{f} \mathbf{s} \boldsymbol{s} \boldsymbol{f} \boldsymbol{f} \mathbf{s} \boldsymbol{s}\end{array}$ \\
\hline $\begin{array}{l}501 \\
\text { GV S R E R I R }\end{array}$ & $\begin{array}{l}511 \\
\mathbf{E} \mathbf{S} \text { GA }\end{array}$ & $\begin{array}{l}521 \\
\text { K K R V F }\end{array}$ & $\begin{array}{l}531 \\
\text { L V P V }\end{array}$ & \\
\hline & $\begin{array}{l}e b \in b b e e b e \\
f \quad s \quad f f s f\end{array}$ & $\begin{array}{l}e \text { e e e e e b e e b } \\
\mathbf{f} \quad \mathbf{s} \quad \mathbf{s}\end{array}$ & & \\
\hline
\end{tabular}

The conservation scale:

$\begin{array}{llllllllll}1 & 2 & 3 & 4 & 5 & 6 & 7 & 8 & 9\end{array}$

Variable Average Conserved

e - An exposed residue according to the neural-network algorithm.

b - A buried residue according to the neural-network algorithm.

f - A predicted functional residue (highly conserved and exposed).

s - A predicted structural residue (highly conserved and buried).

- Insufficient data - the calculation for this site was performed on less than $10 \%$ of the sequences. 
Suppl. 4 Evolutionary conservation of amino acid positions in Sisig $2 \mathrm{Ab}$ protein.

\section{ConSurf Results}

\begin{tabular}{|c|c|c|c|c|}
\hline 1 & 11 & 21 & 31 & 41 \\
\hline MAFIA PRF K & C P P S T & RE PAG GAG S R & P G R V N C S v S S & TAVVDAERLE \\
\hline 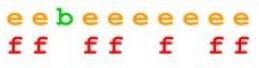 & $b e e e e e b e b$ & eeeeeeee & $\underset{\mathbf{s}}{\mathrm{b} b} \mathbf{b} \in \mathrm{s}$ & $b b b b e b e e e e$ \\
\hline 51 & 61 & 71 & 81 & 91 \\
\hline$C L S \quad G P P P S P$ & P T L PGGFGE & A I L N K E A M VA & A A A E A & $R A A A E A G E V$ \\
\hline$b e \in b e b e e e$ & $\underset{f}{e}$ & 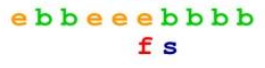 & 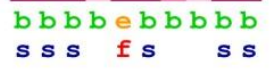 & $\begin{array}{c}e b \vec{b} b \mathrm{~b} b e \mathrm{~b} \\
\mathbf{s} \quad \mathbf{s} \quad \mathbf{f}\end{array}$ \\
\hline 101 & 111 & 121 & 131 & 141 \\
\hline A R M A Q D H $\mathrm{R}$ & DFS PRDTED & SF L A I E L R R T & E V GW Q S S R RA & GLELLEDE E F \\
\hline$b e b b e e e e e$ & eeeeeeee & eeebeebee & $\begin{array}{l}\text { e e e eeeeee } \\
f\end{array}$ & eeebeeeee \\
\hline 151 & 161 & 171 & 181 & 191 \\
\hline S S I L SDEAED & GD D D GESTEG & VVAVKSARRS & E R R A R R VRA A & MKAAKFISIG \\
\hline eeeeeebee & eeeeeee eb & $\underset{f}{e b b b e} \underset{f}{e} e e e$ & eeeeeeee & eeeeeeee \\
\hline 201 & 211 & 221 & 231 & 241 \\
\hline K P V A S S S K & K R L K G C R N P L & GCFYKMTGPR & L L T A K Q EVE F & $S E G I Q D L L K L$ \\
\hline ee eeeeee e & $\begin{array}{c}\text { eeeeee } e^{e b} \\
f f\end{array}$ & $\begin{array}{l}e b b \text { e e eb ebe } \\
\mathbf{f} \quad \mathbf{f}\end{array}$ & $\begin{array}{l}b b \in b \in e \in b \in b \\
\text { s } s f \quad f f\end{array}$ & $\begin{array}{l}\bar{b} e \in \bar{b} e \in b \bar{b} \in b \\
\mathbf{s} \quad \mathbf{s} \mathbf{f} \quad \mathbf{s}\end{array}$ \\
\hline 251 & 261 & 271 & 281 & 291 \\
\hline E A I $Q$ K E L A H Y & NGDEPTFSQW & A A A A G T E N T & L R K R L N Y GVY & C K N R M V KS NV \\
\hline $\begin{array}{l}\text { e e bee e beee } \\
f\end{array}$ & e e e e e e eb & $b e b b e b e e e$ & $b e e b e e b e e$ & $\begin{array}{c}b e e \in b e b b b \\
\mathbf{f} \quad \mathbf{s} \mathbf{s} \mathbf{s}\end{array}$ \\
\hline 301 & 311 & 321 & 331 & 341 \\
\hline R LVISIARE H & EGPGMDF & I Q E GMQG L I R & G A E K F DASKG & FR F T Y SH W \\
\hline $\begin{array}{l}e b b b b b b e e b \\
f \mathbf{s} s \boldsymbol{s} \boldsymbol{s} \boldsymbol{s} f \boldsymbol{f}\end{array}$ & $\begin{array}{l}e e e b e b e b \\
f f f f \quad f f s\end{array}$ & $\begin{array}{l}b \in e b b e b b b e \\
s f f s \quad f s \quad f \quad f\end{array}$ & $\begin{array}{l}b b e e b e e e e \\
\text { s sffsf fff }\end{array}$ & $\begin{array}{l}e a b b b b b b b \\
f \boldsymbol{f} \mathbf{s} s \boldsymbol{s} \boldsymbol{s} \mathbf{s} s \mathbf{s}\end{array}$ \\
\hline 351 & 361 & 371 & 381 & 391 \\
\hline I K Q A I R K S V L & EQ T H I I R L PS & H M A E A S S R VK & E CRRR L H R $Q$ L & KRLPS NETIA \\
\hline 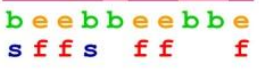 & $\begin{array}{l}e \in e b b \in b b b \\
f f f \boldsymbol{f} f \quad s\end{array}$ & $\begin{array}{l}b b b e b b e e b e \\
\mathbf{s} \quad f \mathbf{s} f \boldsymbol{f} \mathbf{s}\end{array}$ & $\begin{array}{l}\text { eb } \\
\mathbf{f}\end{array}$ & $\begin{array}{lll}f & f & f\end{array}$ \\
\hline 401 & 411 & 421 & 431 & 441 \\
\hline L D T G M P I R R V & E A A M S L PR Y S & VSLSSKVGCT & DVTYQEIMPD & TSAETAEEVL \\
\hline $\begin{array}{c}e \in b \text { e } b b b e f b \\
\mathbf{f} \quad f \mathbf{s}\end{array}$ & 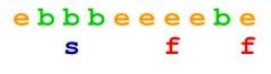 & $\begin{array}{llll}\mathbf{f} & \mathbf{f} & \mathbf{f} & \mathbf{f}\end{array}$ & $\underset{f}{e} \in \mathbb{f}$ & $\begin{array}{r}e \text { e e e b e e b } \\
\mathbf{f}\end{array}$ \\
\hline 451 & 461 & 471 & 481 & 491 \\
\hline H R W L M K K D V D & KALDSLS PRE & K QVIRYRFGI & E G GR P RT L н D & I GQ L M GV S R E \\
\hline 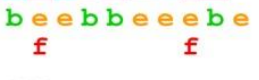 & 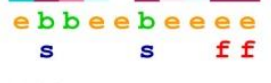 & $\begin{array}{c}e=b b e b=b b b \\
f \mathbf{s} \quad f \quad s\end{array}$ & $\begin{array}{l}\text { ff } f \text { f } f f \\
\text { f }\end{array}$ & $\begin{array}{l}b b \in b b \in b b e e \\
\mathbf{s} s \quad s \quad f f f\end{array}$ \\
\hline 501 & 511 & 521 & 531 & \\
\hline R I R Q I EL G A F & RK L R A K K K V Q & $S L Q$ H Y L $Q P$ & s & \\
\hline $\begin{array}{l}e b e \in b e b e b b \\
f \quad f f \mathbf{f} f \quad s\end{array}$ & $\begin{array}{l}e e b e e e e e e \\
f f \boldsymbol{f f} f\end{array}$ & $e \bar{b} e e b b e e e$ & ee & \\
\hline
\end{tabular}

The conservation scale:

$\begin{array}{lllllllll}1 & 2 & 3 & 4 & 5 & 6 & 7 & 8 & 9\end{array}$

Variable Average Conserved

e - An exposed residue according to the neural-network algorithm.

b - A buried residue according to the neural-network algorithm.

f - A predicted functional residue (highly conserved and exposed).

s - A predicted structural residue (highly conserved and buried).

- Insufficient data - the calculation for this site was performed on less than $10 \%$ of the sequences. 
Suppl. 5 Evolutionary conservation of amino acid positions in Sisig 2B protein.

\section{ConSurf Results}

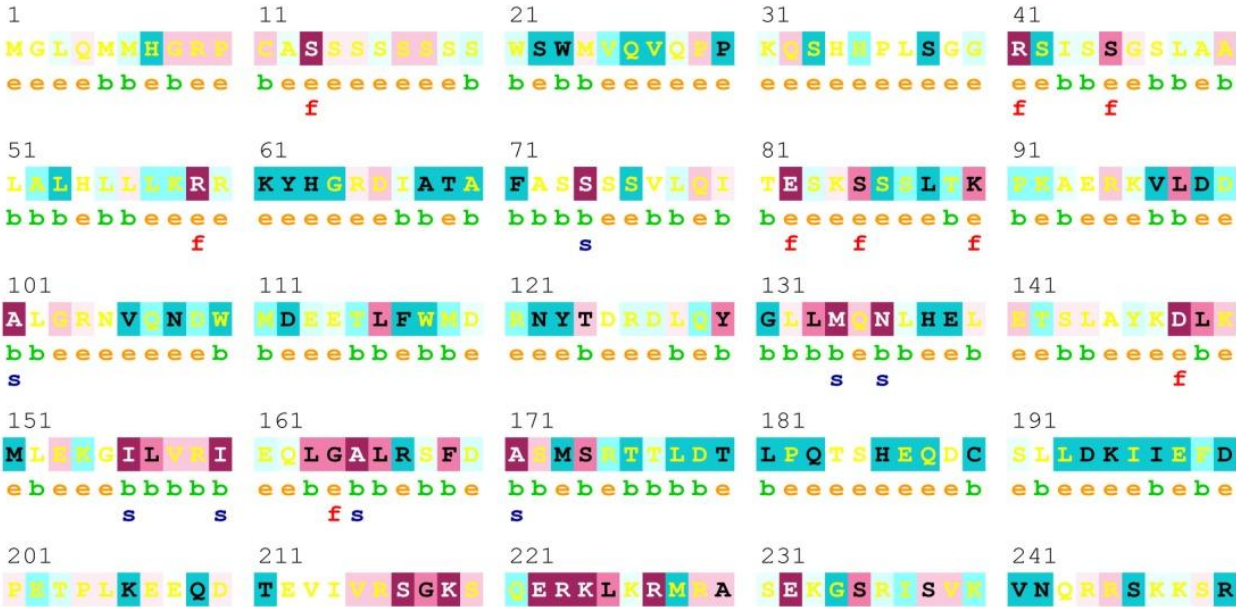

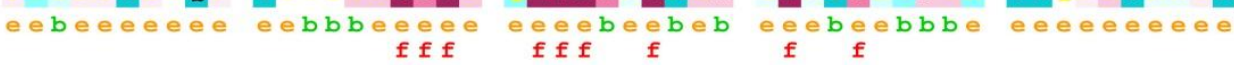

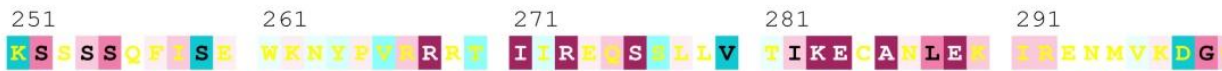

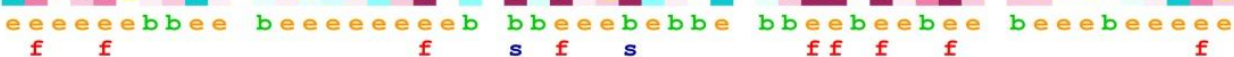

$\begin{array}{lllll}301 & 311 & 321 & 331 & 341\end{array}$

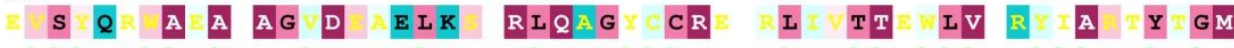

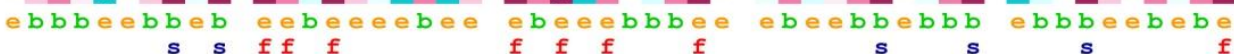

$\begin{array}{lllll}351 & 361 & 371 & 381 & 391\end{array}$

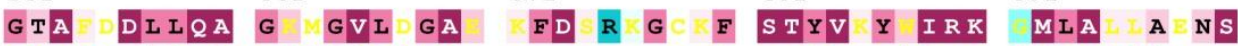

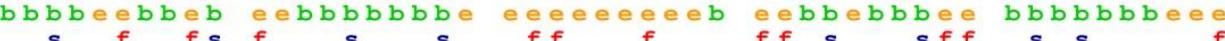

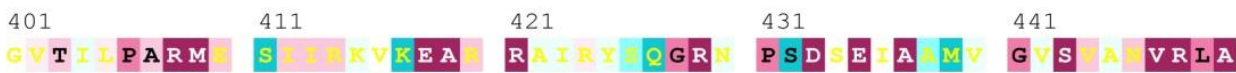

$e b b e b b b e b e$ ebbeebeebee eebeeeeee eeeeebbebb $b b b b b e b e b b$

$\begin{array}{lllll}451 & 461 & 471 & 481 & 491\end{array}$

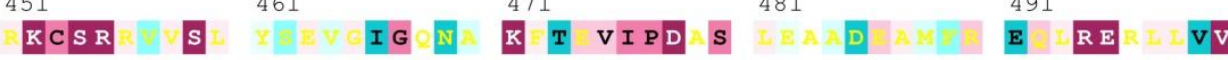

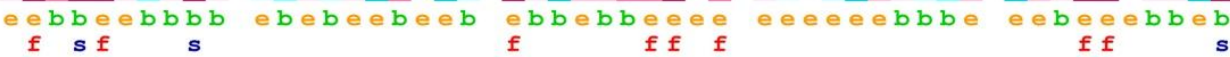

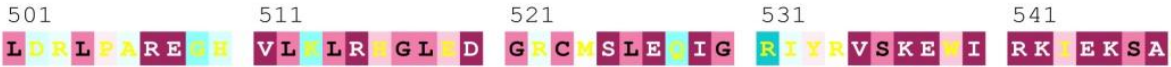

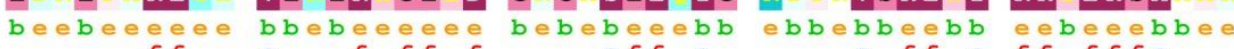

$551 \quad 561$

R $\mathbf{V}$ V R L $D$ C R

beeebeeeb eebeee

The conservation scale:

\begin{tabular}{llllllll|l|l|}
1 & 2 & 3 & 4 & 5 & 6 & 7 & 8 & 9
\end{tabular}

Variable Average Conserved

e - An exposed residue according to the neural-network algorithm.

b - A buried residue according to the neural-network algorithm.

f - A predicted functional residue (highly conserved and exposed)

s - A predicted structural residue (highly conserved and buried).

- Insufficient data - the calculation for this site was performed on less than $10 \%$ of the sequences.

Suppl. 6 Evolutionary conservation of amino acid positions in Sisig 3 protein. 


\section{ConSurf Results}

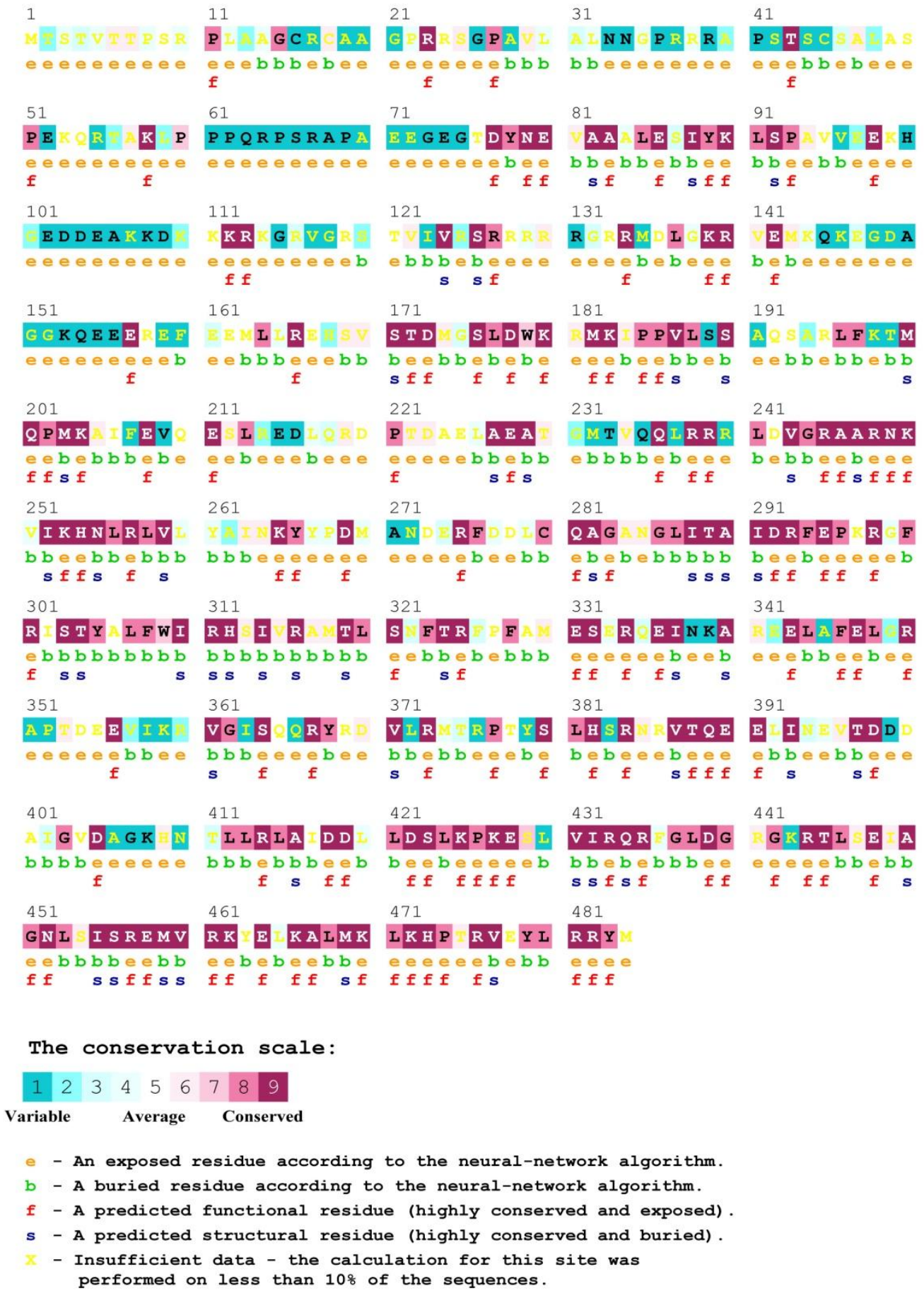

Suppl. 7 Evolutionary conservation of amino acid positions in Sisig 5 protein. 


\section{ConSurf Results}

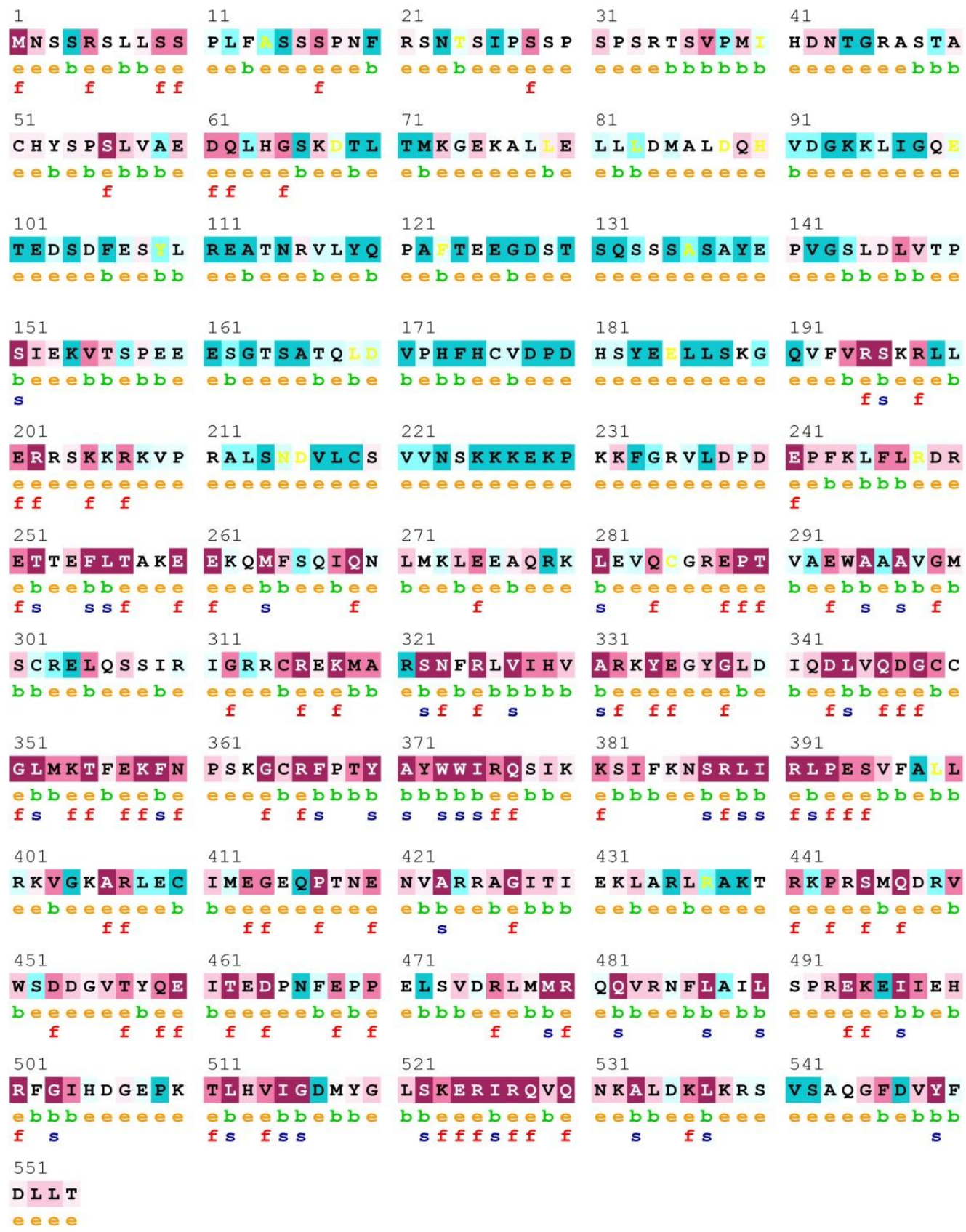

The conservation scale:

$\begin{array}{lllllllll}1 & 2 & 3 & 4 & 5 & 6 & 7 & 8 & 9\end{array}$

Variable Average Conserved

e - An exposed residue according to the neural-network algorithm.

b - A buried residue according to the neural-network algorithm.

f - A predicted functional residue (highly conserved and exposed).

s - A predicted structural residue (highly conserved and buried).

- Insufficient data - the calculation for this site was performed on less than $10 \%$ of the sequences. 
Suppl. 9 the sigma factor genes identified in Arabidopsis thaliana, rice, and maize.

\begin{tabular}{llll}
\hline SPECIES & ARABIDOPSIS THALIANA & ORYZA SATIVA & ZEA MAYS \\
\hline \multirow{2}{*}{ SIG1 } & AT1G64860 & OS08G0163400 & GRMZM2G543629 \\
& & ORMZM2G006736 & GRMZM2G100086 \\
\cline { 2 - 4 } SIG2 & AT1G08540 & & GRMZM2G003182 \\
& & & GRMZM2G143392 \\
\hline SIG3 & & OS05G0589200 & GRMZM5G830932 \\
\hline SIG4 & AT3G53920 & & GRMZM2G077436 \\
\hline SIG5 & AT5G13730 & OS05G0586600 & GRMZM2G144196 \\
\hline SIG6 & AT5G24120 & OS08G0242800 & \\
\hline
\end{tabular}

Suppl. 10 The promoter cis-acting elements of the sigma factor genes in millet.

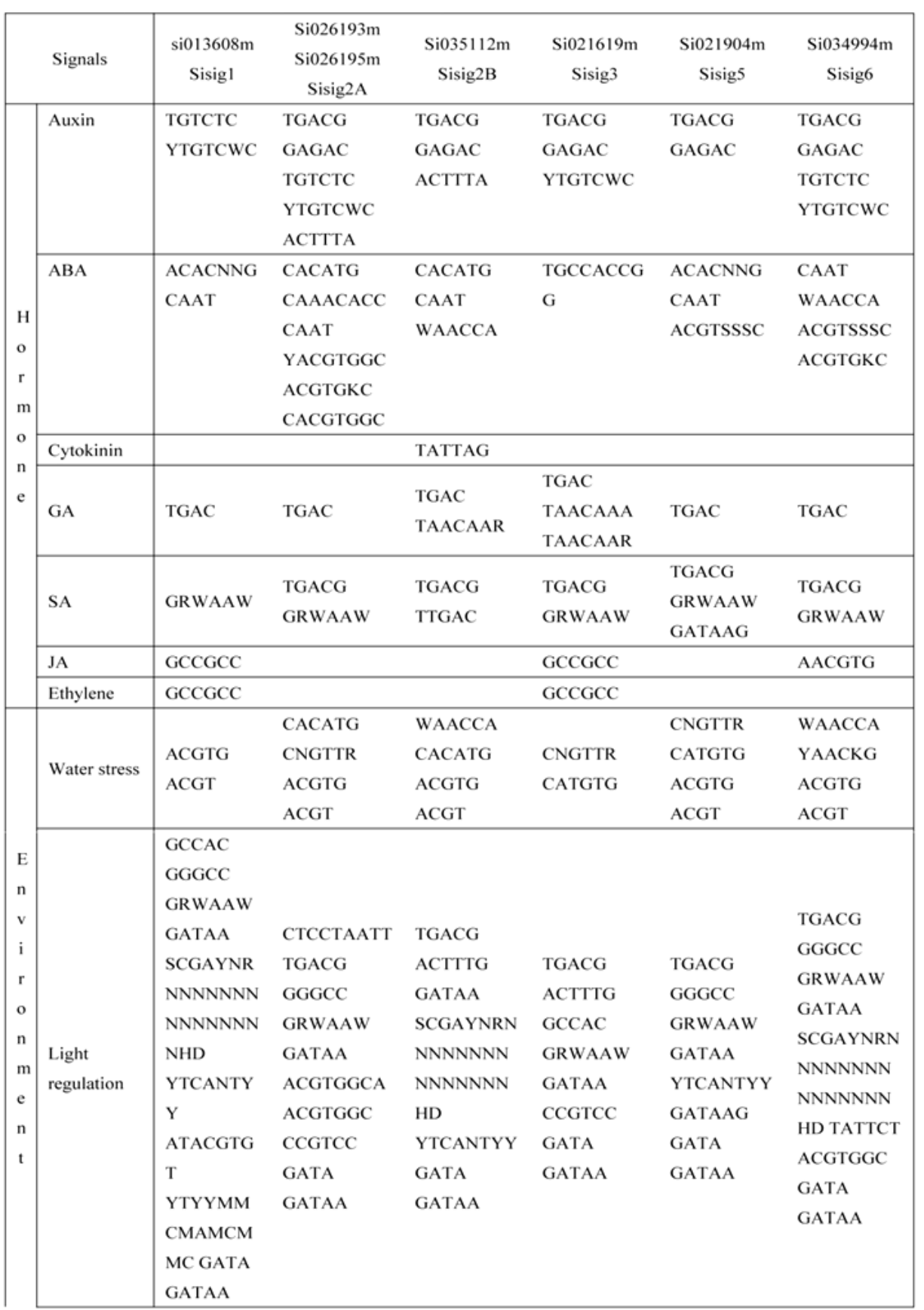




\begin{tabular}{|c|c|c|c|c|c|c|c|}
\hline & $\begin{array}{l}\text { Copper } \\
\text { response }\end{array}$ & GTAC & & GTAC & GTAC & GTAC & GTAC \\
\hline & $\begin{array}{l}\text { Calcium } \\
\text { response }\end{array}$ & $\begin{array}{l}\text { VCGCGB } \\
\text { MACGYG } \\
\text { B }\end{array}$ & MACGYGB & MACGYGB & $\begin{array}{c}\text { VCGCGB } \\
\text { MACGYGB }\end{array}$ & $\begin{array}{c}\text { VCGCGB } \\
\text { MACGYGB }\end{array}$ & $\begin{array}{c}\text { VCGCGB } \\
\text { MACGYGB }\end{array}$ \\
\hline & $\begin{array}{l}\text { Iron } \\
\text { deficiency }\end{array}$ & & CACGTGG & & & CACGTGG & \\
\hline & $\begin{array}{l}\text { Sulfurrespo } \\
\text { nse }\end{array}$ & & GAGAC & GAGAC & GAGAC & GAGAC & GAGAC \\
\hline & $\begin{array}{l}\text { phosphorus } \\
\text { starvation }\end{array}$ & & & GNATATNC & & & \\
\hline & Salt stress & GAAAAA & GAAAAA & & & GAAAAA & GAAAAA \\
\hline & $\begin{array}{l}\text { Oxygen } \\
\text { response }\end{array}$ & GTAC & GTAC & GTAC & GTAC & GTAC & GTAC \\
\hline & $\begin{array}{l}\mathrm{CO}_{2} \\
\text { response }\end{array}$ & & & GANTTNC & GANTTNC & GANTTNC & \\
\hline & $\begin{array}{l}\text { Low } \\
\text { temperature }\end{array}$ & $\begin{array}{l}\text { CANNTG } \\
\text { CANNTG }\end{array}$ & $\begin{array}{l}\text { CANNTG } \\
\text { CANNTG }\end{array}$ & $\begin{array}{l}\text { CANNTG } \\
\text { CANNTG }\end{array}$ & $\begin{array}{l}\text { CANNTG } \\
\text { CANNTG }\end{array}$ & $\begin{array}{l}\text { CANNTG } \\
\text { CANNTG }\end{array}$ & $\begin{array}{l}\text { CANNTG } \\
\text { CANNTG }\end{array}$ \\
\hline & $\begin{array}{l}\text { heatshock } \\
\text { protein }\end{array}$ & CCAAT & CCAAT & CCAAT & & CCAAT & CCAAT \\
\hline & Dof protein & AAAG & AAAG & AAAG & AAAG & AAAG & AAAG \\
\hline & histone & CCGTCG & & & & ACGTCA & ACGTCA \\
\hline t & $\begin{array}{l}\text { storage } \\
\text { protein }\end{array}$ & & $\begin{array}{l}\text { CAAACAC } \\
\text { CNAACAC }\end{array}$ & & & & \\
\hline . & cyclin & & & & AACGG & AACGG & AACGG \\
\hline $\mathrm{n}$ & $\begin{array}{l}\text { Chloroplast } \\
\text { ribosomal } \\
\text { protein }\end{array}$ & & & $\begin{array}{l}\text { ATGGTA } \\
\text { ATGGTATT }\end{array}$ & & & \\
\hline $\begin{array}{l}\mathrm{E} \\
\mathrm{n}\end{array}$ & $\alpha$-amylase & CGACG & $\begin{array}{l}\text { TGACGT } \\
\text { AATTAAA } \\
\text { TATCCA }\end{array}$ & TGACGT & $\begin{array}{l}\text { TAACAAA } \\
\text { TAACARA } \\
\text { AATAAA }\end{array}$ & AATAAA & $\begin{array}{l}\text { AATAAA } \\
\text { TGACGT } \\
\text { CGACG }\end{array}$ \\
\hline 2 & $\beta$-amylase & & & TACTATT & & & \\
\hline $\begin{array}{l}y \\
0\end{array}$ & isoamylase & TGACT & TGACT & TGACT & & & \\
\hline e & $\begin{array}{l}\text { glutamine } \\
\text { synthetase }\end{array}$ & TTATTT & TTATTT & & & & TTATTT \\
\hline $\begin{array}{l}P \\
i \\
g \\
m \\
e \\
n \\
t\end{array}$ & $\begin{array}{l}\text { phytochrom } \\
\text { e }\end{array}$ & CAAT & CAAT & $\begin{array}{c}\text { CAAT } \\
\text { AACCAA }\end{array}$ & $\begin{array}{l}\text { AACCAA } \\
\text { CGGATA }\end{array}$ & CAAT & $\begin{array}{l}\text { CAAT } \\
\text { AACCAA }\end{array}$ \\
\hline $\begin{array}{l}\mathrm{S} \\
\mathrm{p}\end{array}$ & tissue & $\begin{array}{l}\text { CAAT } \\
\text { CACGTG }\end{array}$ & $\begin{array}{l}\text { CAAT } \\
\text { CACGTG }\end{array}$ & $\begin{array}{l}\text { CAAT } \\
\text { CACGTG }\end{array}$ & GATA & $\begin{array}{l}\text { CAAT } \\
\text { CACGTG }\end{array}$ & $\begin{array}{l}\text { CAAT } \\
\text { GATA }\end{array}$ \\
\hline e & & GATA & GATA & GATA & & GATA & \\
\hline i & $\begin{array}{l}\text { Mesophyll } \\
\text { cell }\end{array}$ & YACT & YACT & YACT & YACT & YACT & YACT \\
\hline c & Fruit & & TGTCACA & & & & \\
\hline $\begin{array}{l}\mathrm{t} \\
\mathrm{y}\end{array}$ & Fibrils & KCACGW & KCACGW & KCACGW & & KCACGW & \\
\hline & $\begin{array}{l}\text { Stimulation } \\
\text { induced }\end{array}$ & & CTGAC & TTGACC & CTGAC & & \\
\hline
\end{tabular}




\begin{tabular}{|c|c|c|c|c|c|c|c|}
\hline & Pollen & GTGA & $\begin{array}{l}\text { GTGA } \\
\text { AGAAA }\end{array}$ & $\begin{array}{l}\text { GTGA } \\
\text { AGAAA }\end{array}$ & GTGA & $\begin{array}{l}\text { GTGA } \\
\text { AGAAA }\end{array}$ & $\begin{array}{l}\text { GTGA } \\
\text { AGAAA }\end{array}$ \\
\hline & Root nodule & СТСТT & $\begin{array}{l}\text { AAAGAT } \\
\text { СТCTT }\end{array}$ & $\begin{array}{l}\text { AAAGAT } \\
\text { СТСTT }\end{array}$ & $\begin{array}{l}\text { AAAGAT } \\
\text { СТСTT }\end{array}$ & AAAGAT & СТCTT \\
\hline & $\begin{array}{l}\text { Polyadenyla } \\
\text { tion }\end{array}$ & & & AATAAT & & & \\
\hline & $\begin{array}{l}\text { Oxidative } \\
\text { phosphoryla } \\
\text { tion }\end{array}$ & TGGGCY & & & TGGGCY & TGGGCY & TGGGCY \\
\hline o & napA & & $\begin{array}{l}\text { CAAACAC } \\
\text { CNAACAC }\end{array}$ & & & & \\
\hline , & $\begin{array}{l}\text { Disease-resi } \\
\text { stant }\end{array}$ & & TGTCA & & TGTCA & & \\
\hline $\mathrm{s}$ & $\begin{array}{l}\text { Sugar } \\
\text { repressive }\end{array}$ & & TTATCC & & TTATCC & & \\
\hline & MYB & & GGATA & GGATA & $\begin{array}{l}\text { MACCWAM } \\
\text { C GGATA }\end{array}$ & & \\
\hline & MYC & & & & & & CAACGTG \\
\hline & E2F & $\begin{array}{l}\text { TYTCCCG } \\
\text { CC }\end{array}$ & & & & $\begin{array}{l}\text { TYTCCCGC } \\
\text { C }\end{array}$ & \\
\hline & RAV1 & & CAACA & & CACCTG & CAACA & \\
\hline & $\begin{array}{l}\text { Flavonoid } \\
\text { biosynthesis }\end{array}$ & & CNGTTR & & CNGTTR & CNGTTR & \\
\hline & $\begin{array}{l}\text { Splice } \\
\text { junction }\end{array}$ & & & & & & TGCAGG \\
\hline & Injured & & NGATT & NGATT & NGATT & NGATT & NGATT \\
\hline
\end{tabular}

